\title{
Examination of Generation Mechanisms for an English Channel Meteotsunami: Combining Observations and Modeling
}

\author{
DAVID A. WiLliams \\ Department of Earth, Ocean and Ecological Sciences, University of Liverpool, Liverpool, United Kingdom \\ KEVIN J. HORSBURGH \\ National Oceanography Centre, Liverpool, United Kingdom \\ DAVID M. SCHULTZ \\ School of Earth and Environmental Sciences, University of Manchester, Manchester, United Kingdom \\ CHRIS W. Hughes \\ Department of Earth, Ocean and Ecological Sciences, University of Liverpool, Liverpool, United Kingdom
}

(Manuscript received 7 August 2018, in final form 16 October 2018)

\begin{abstract}
On the morning of 23 June 2016, a 0.70-m meteotsunami was observed in the English Channel between the United Kingdom and France. This wave was measured by several tide gauges and coincided with a heavily precipitating convective system producing $10 \mathrm{~m} \mathrm{~s}^{-1}$ wind speeds at the $10-\mathrm{m}$ level and $1-2.5-\mathrm{hPa}$ surface pressure anomalies. A combination of precipitation rate cross correlations and NCEP-NCAR Reanalysis 1 data showed that the convective system moved northeastward at $19 \pm 2 \mathrm{~m} \mathrm{~s}^{-1}$. To model the meteotsunami, the finite element model Telemac was forced with an ensemble of prescribed pressure forcings, covering observational uncertainty. Ensembles simulated the observed wave period and arrival times within minutes and wave heights within tens of centimeters. A directly forced wave and a secondary coastal wave were simulated, and these amplified as they propagated. Proudman resonance was responsible for the wave amplification, and the coastal wave resulted from strong refraction of the primary wave. The main generating mechanism was the atmospheric pressure anomaly with wind stress playing a secondary role, increasing the first wave peak by $16 \%$ on average. Certain tidal conditions reduced modeled wave heights by up to $56 \%$, by shifting the location where Proudman resonance occurred. This shift was mainly from tidal currents rather than tidal elevation directly affecting shallow-water wave speed. An improved understanding of meteotsunami return periods and generation mechanisms would be aided by tide gauge measurements sampled at less than 15-min intervals.
\end{abstract}

\section{Introduction}

On the morning of 23 June 2016, a 0.70-m-high, 35-min-period wave coinciding with convective storms was observed in the English Channel (Fig. 1). This study shows this wave to be a meteorologically generated tsunami, also known as a meteotsunami.

Meteotsunamis are atmospherically generated shallowwater waves in the tsunami frequency band, with periods between $2 \mathrm{~min}$ and $2 \mathrm{~h}$ (Monserrat et al. 2006). Meteotsunami

Corresponding author: David A. Williams, david.williams2@ liverpool.ac.uk wave heights are on the order of 0.1-1 m (Monserrat et al. 2006). Meteotsunamis have sporadically occurred in water bodies on every continent (except Antarctica, where there is absence of evidence). In specific locations, such as Nagasaki Bay in Japan (Hibiya and Kajiura 1982), Ciutadella Harbor in Menorca (Rabinovich and Monserrat 1998), or Split in Croatia (Šepić et al. 2012), meteotsunamis repeatedly occur and can reach up to $6 \mathrm{~m}$. They are also recurrent in the Laurentian Great Lakes (Bechle et al. 2016), where strong rip currents are particularly dangerous (Anderson et al. 2015; Linares and Bechle 2018). They have caused substantial economic losses; for example, a 6-m meteotsunami produced $\$ 7$ million of damages in 


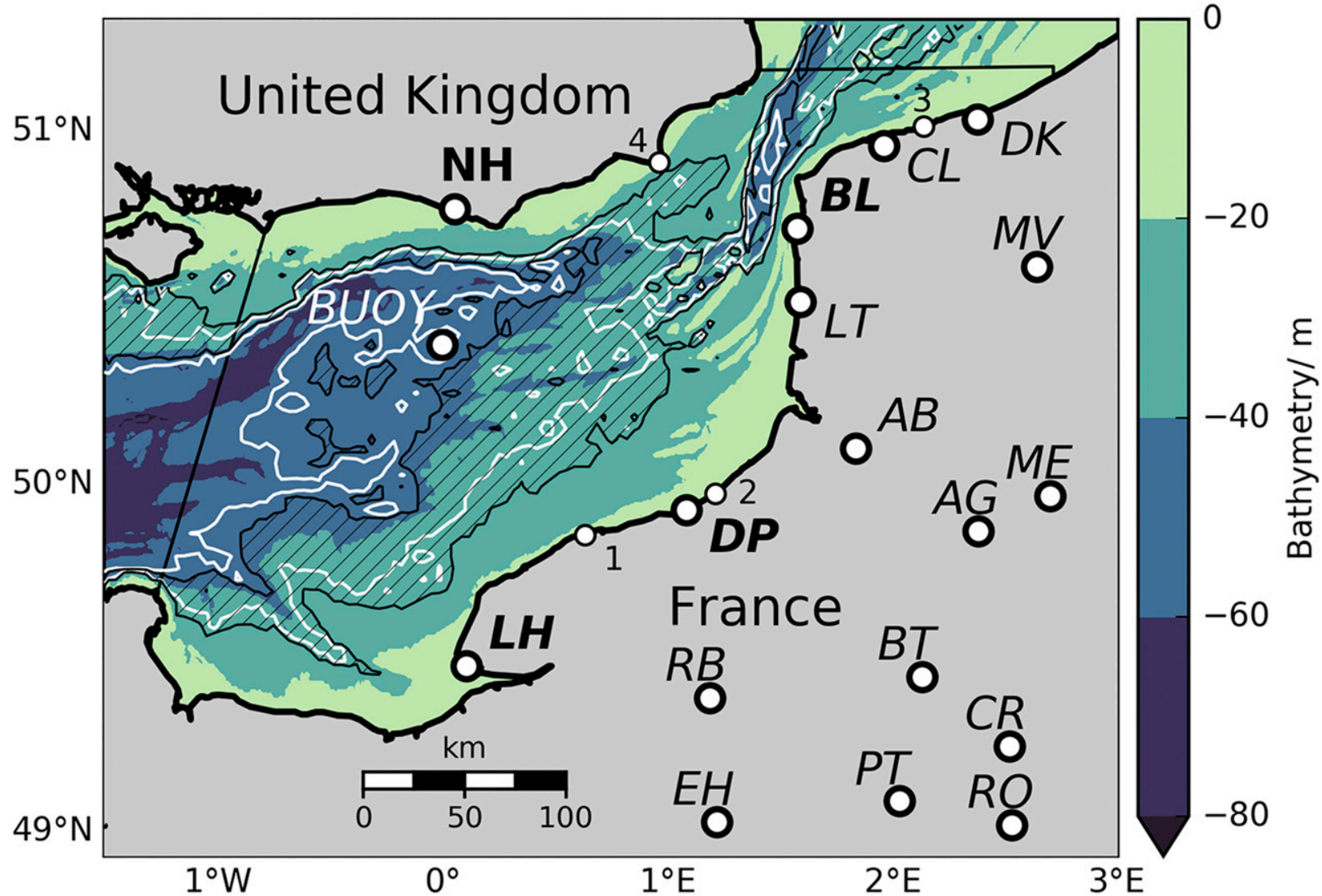

FIG. 1. English Channel bathymetry (Ioc 2008) in filled contours from shallow (light blue) to deep (dark blue). The color saturates when bathymetry is deeper than $80 \mathrm{~m}$. The black, hatched area is the still water level region where $0.9 \leq \mathrm{Fr} \leq 1.1$. The area bounded by white lines is the equivalent region with $-0.5-\mathrm{m}$ tidal elevation and $-1 \mathrm{~m} \mathrm{~s}^{-1}$ current approximations. Tide gauges locations have bold typeface, atmospheric stations have italic typeface, and locations with both tide gauges and atmospheric stations have italic bold typeface. The locations are Newhaven (NH), Le Havre (LH), Dieppe (DP), Le Touquet (LT), Boulogne (BL), Dunkirt (DK), Rouen Boos (RB), Evreux Huest (EH), Beauvais Tille (BT), Roissy (RO), Creil (CR), Pointoise (PT), Amiens Glisy (AG), Abbeville (AB), Meaulte (ME), Merville (MV), Calais (CL), Paluel (1), Penly (2), Gravelines (3), Dungeness B (4), and Greenwich Lightship buoy (BUOY). A 100-km scale is given. The model open boundaries are shown as thin black lines. Land is shaded gray. Thick black lines are coastlines from the Basemap Python package.

Vela Luka Bay in 1978 (Vučetić et al. 2009). Furthermore, they may cause injury (Sibley et al. 2016) and sometimes fatalities (Monserrat et al. 2006; Linares and Bechle 2018).

In the United Kingdom, there have been recorded meteotsunamis along the south coast in 2011 (Tappin et al. 2013) and along the east coast in 2008 and 2015 (Sibley et al. 2016). Although they are seldom reported, damage to boats has been associated with possible meteotsunamis (Haslett et al. 2009). Also, in 2015, a confirmed meteotsunami in Scotland was related to at least one serious injury (Sibley et al. 2016), and, in 1929, a suspected meteotsunami was related to two deaths along the U.K. southern coastline (Haslett et al. 2009). In 2017, a large tsunamilike wave was noticed at high tide in the Netherlands and was reported by televised weather reports as a meteotsunami generated by a passing convective system.

However, understanding meteotsunami generation around the United Kingdom, and in wider European seas, remains poor because these reports lack quantitative generation mechanism explanations. To date, there is no study in this region that relates the observed waves to their meteorological initiation and amplification. That is the motivation for this work. We use combined observations and numerical modeling to quantitatively understand the generation mechanisms, the relative role of atmospheric pressure and wind stress, and the wave amplification.

Meteotsunamis are initiated by pressure and wind stress from moving atmospheric weather systems (Monserrat et al. 2006). Typically, meteotsunami-generating atmospheric systems are hundreds of kilometers in scale and last a few hours - they are mesoscale systems. Since the atmospheric pressure perturbations $(\sim \pm 1 \mathrm{hPa})$ and $10-\mathrm{m}$ wind speeds $\left(\sim 10 \mathrm{~m} \mathrm{~s}^{-1}\right)$ in mesoscale systems typically produce centimeter-scale sea surface perturbations, amplification mechanisms are required for large meteotsunamis (Monserrat et al. 2006). This requirement 
for wave amplification makes meteotsunamis different from storm surges, which are generated over larger time and space scales by cyclones with deep pressure lows $(>50 \mathrm{hPa}$ lower than background pressure) and strong 10-m wind speeds $\left(>20 \mathrm{~m} \mathrm{~s}^{-1}\right)$.

Amplification up to an order of magnitude can be provided by resonance between the meteotsunami and atmospheric forcing (external resonance) (Monserrat et al. 2006). Greenspan resonance and Proudman resonance are two candidate external resonances. Greenspan resonance occurs when the atmospheric forcing speed along the coastline is the same as a coastally trapped edge wave (Greenspan 1956), whereas Proudman resonance occurs when the atmospheric forcing speed is the same as the shallow-water wave speed (Proudman 1929). Numerical models have provided evidence supporting Greenspan resonance in the Great Lakes (Ewing et al. 1954; Anderson et al. 2015) and Proudman resonance in Adriatic (Šepić et al. 2015), Balearic (Ličer et al. 2017), and East China Sea (Hibiya and Kajiura 1982). Frère et al. (2014) and Tappin et al. (2013) have suggested that Proudman resonance was responsible for observed meteotsunamis around the United Kingdom, but this has never been demonstrated through numerical modeling, as we do here.

Acquiring evidence for meteotsunami mechanisms away from coastal tide gauges is difficult but can be achieved with a dense oceanographic observational network (Sheremet et al. 2016); unfortunately, no such network is in the English Channel. Therefore, we use numerical models for evidence of external resonance. Our approach is to prescribe an analytic atmospheric forcing, guided by observations, to force a hydrodynamic ocean model. We refer to this as a synthetic model, following Ličer et al. (2017). There are two advantages to synthetic models over models forced by numerical weather prediction output (NWP models), despite NWP models' capability for more detailed forcing. First, synthetic models are simpler than NWP models and simulate comparable wave heights and arrival times (Anderson et al. 2015). Second, synthetic models allow full control in sensitivity studies when investigating the relative importance of generation mechanisms such as wind stress and pressure disturbances (Bechle and Wu 2014; Anderson et al. 2015; Šepić et al. 2015). For instance, in Lake Erie, wind stress accounts for $30 \%-60 \%$ of wave height (Anderson et al. 2015), whereas in the Adriatic, pressure accounts for $90 \%$ of wave height (Šepić et al. 2015).

Meteotsunamis may undergo further amplification when approaching coastlines. Basin bathymetry and the coastline shape (referred to in combination as "geomorphology") amplify meteotsunamis through refraction and shoaling (Levin and Nosov 2009, 311-345). Simple calculations (Green's law) suggest that geomorphology in the English Channel amplifies waves by less than an order of magnitude. In this study, we examine amplification due to both external resonance and geomorphology. Because the English Channel is macrotidal $(>4-\mathrm{m}$ tidal range), we also consider the sensitivity of meteotsunami growth to tides. In South Korea, another macrotidal basin, modeled wave heights change by up to $11 \%$ from tidal elevation affecting Proudman resonance and change by $9 \%$ from tidal currents causing refraction (Choi et al. 2014). Therefore, tides may affect wave growth as much as atmospheric forcing.

This paper presents the observations of the 23 June 2016 meteotsunami in the English Channel and shows, with the help of a prescribed analytic atmospheric forcing, the relative importance of the pressure field versus the wind field, external resonance in the meteotsunami generation, the sensitivity in simulations of external resonance to observational uncertainties, and the sensitivity of wave heights to tides. Progress toward operational hazard warning systems for meteotsunamis, as is being worked on in the Adriatic (Vilibić et al. 2016), requires improved regional understanding of meteotsunami generation. We present and analyze oceanographic and atmospheric observations in section 2 and then present numerical modeling in section 3 . Section 4 concludes and gives recommendations for future work.

\section{Observations}

\section{a. Sea surface observations}

The tide gauge locations are shown in Fig. 1, and 23 June 2016 water-level time series are shown in Fig. 2. The tidal records show that the English Channel is macrotidal, with tidal ranges of 7-8 $\mathrm{m}$ near France and $5 \mathrm{~m}$ near the United Kingdom. The sea level signal was high-pass filtered to isolate the high-frequency disturbances. After removing periods greater than $2 \mathrm{~h}$, the largest residual wave height (from peak to trough; red boxes in Fig. 2) measured at Boulogne, France, was $0.78 \mathrm{~m}$ and at Dieppe, France, was $0.42 \mathrm{~m}$ (BL and DP in Fig. 1). No significant residual was measured at Le Havre, France (LH; Fig. 1). Data were missing from 0527-0534 UTC each day at French tide gauge stations (Fig. 2) and 0048-0149 UTC at Le Havre, but this did not impede analysis of wave characteristics.

The 1-min sampled French radar tide gauges also showed that the dominant period of this perturbation was 30-35 min (Fig. 2), within accepted tsunami-period limits (Monserrat et al. 2006). This dominant tsunami signal, isolated with a 10-60-min-period bandpass filter, 

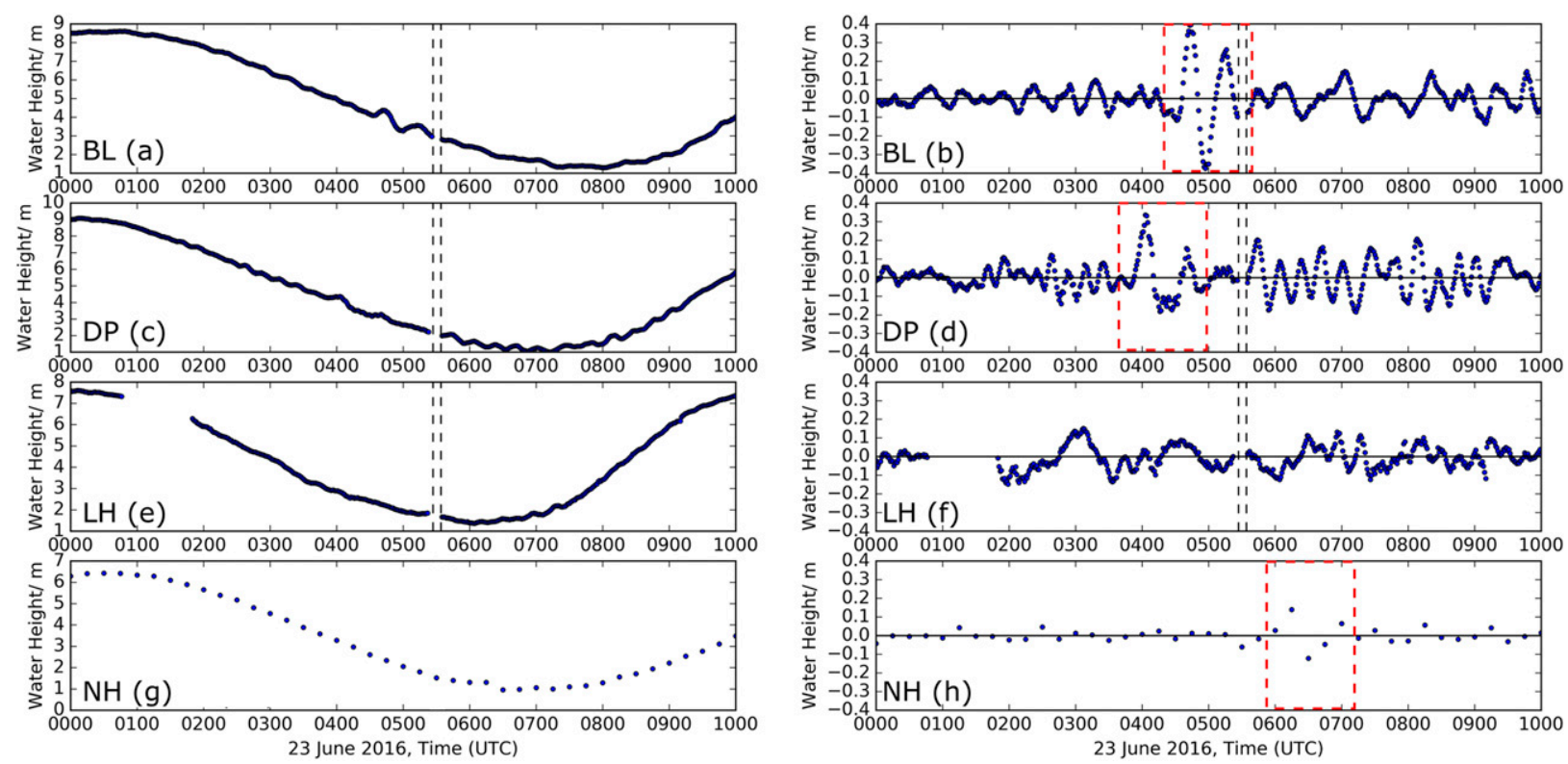

FIG. 2. (left) Tide gauge raw data. (right) High-pass filtered tide gauge observations ( $<2$ h periods) at (a),(b) BL, (c),(d) DP, (e),(f) LH, and (g),(h) NH. The red box indicates meteotsunami arrival. Black dashed lines highlight missing data between 0527 and 0534 UTC inclusive.

had similar wave heights to the nontidal sea level residual $-0.70 \mathrm{~m}$ at Boulogne and $0.43 \mathrm{~m}$ at Dieppe. We took these values as representative wave heights and were deemed large enough to be a meteotsunami (Monserrat et al. 2006). We defined the arrival time as the time at which the residual water level was half of the first peak (which may not be the maximum residual water level) and directly preceded the first peak. The arrival times were 0447 UTC at Boulogne and 0358 UTC at Dieppe, near midtide in France (Fig. 2). The Newhaven, United Kingdom, tide gauge (NH; Fig. 1) suggested that a $0.26-\mathrm{m}$ high wave arrived later, at $0608 \pm$ 0007 UTC. However, owing to the $15-\mathrm{min}$ data at Newhaven, there was high uncertainty in wave height and arrival time at this location.

\section{b. Atmospheric observations}

Convective storms and heavy precipitation were reported across western Europe between 22 and 23 June 2016. Figures $3 \mathrm{a}-\mathrm{c}$ shows $1-\mathrm{km}$ gridded composite radarderived precipitation rates over the English Channel at 0220, 0320, and 0440 UTC, respectively. A small stratiform-trailing convective storm was embedded in light precipitation $\left(<5 \mathrm{~mm} \mathrm{~h}^{-1}\right)$, moving northeastward over the English Channel.

In the following section, the atmospheric properties of this convective system are quantified, and its potential for meteotsunami generation is analyzed. The important atmospheric properties for wave initiation are wind stress and pressure perturbation amplitude.

\section{1) Pressure Perturbations AND Wind Stress}

To analyze the convective system pressure perturbations, the total measured pressure was high-pass filtered. Figure 4a shows that the maximum pressure perturbations were generally within $\pm 1.5 \mathrm{hPa}$. As the convective system progressed northeastward (cf. Fig. 4 and Fig. 3), the high pressure anomaly (mesohigh) strengthened, with low pressure anomalies (mesolows) forming ahead of (presquall low) and behind (wake low) the mesohigh. The pressure anomalies farther inland, between EvreuxHuest, Pointoise-Aero, Creil, Roissy, Beauvais-Tille, Amieres Glisy, Meaulte, and Merville-Calonne (see locations at Fig. 1) France, also show a presquall low and mesohigh progressing northeastward. Figure $3 \mathrm{~d}$ shows the interpretation of the convective system at 0320 UTC, guided by the low-high-low pressure pattern described in Markowski and Richardson (2011).

Figure $4 \mathrm{~b}$ shows that at Le Touquet, Boulogne, and Calais, France, moderate winds were measured between the presquall low and the mesohigh, interpreted as the gust front. At Le Touquet and Dunkirk, France, there were also peak winds between the wake low and mesohigh. At Le Touquet, the maximum 10-m wind speed measured prior to the mesohigh was $8 \mathrm{~m} \mathrm{~s}^{-1}$ and reached a maximum of $10 \mathrm{~m} \mathrm{~s}^{-1}$ after the mesohigh. The Greenwich Lightship buoy (BUOY in Fig. 1) also showed a $+1.3-\mathrm{hPa}$ high pressure anomaly and $11 \mathrm{~m} \mathrm{~s}^{-1} 14-\mathrm{m}$ wind speeds between 0300 and 0400 UTC (sampled once per hour), broadly agreeing with in situ land station observations. 

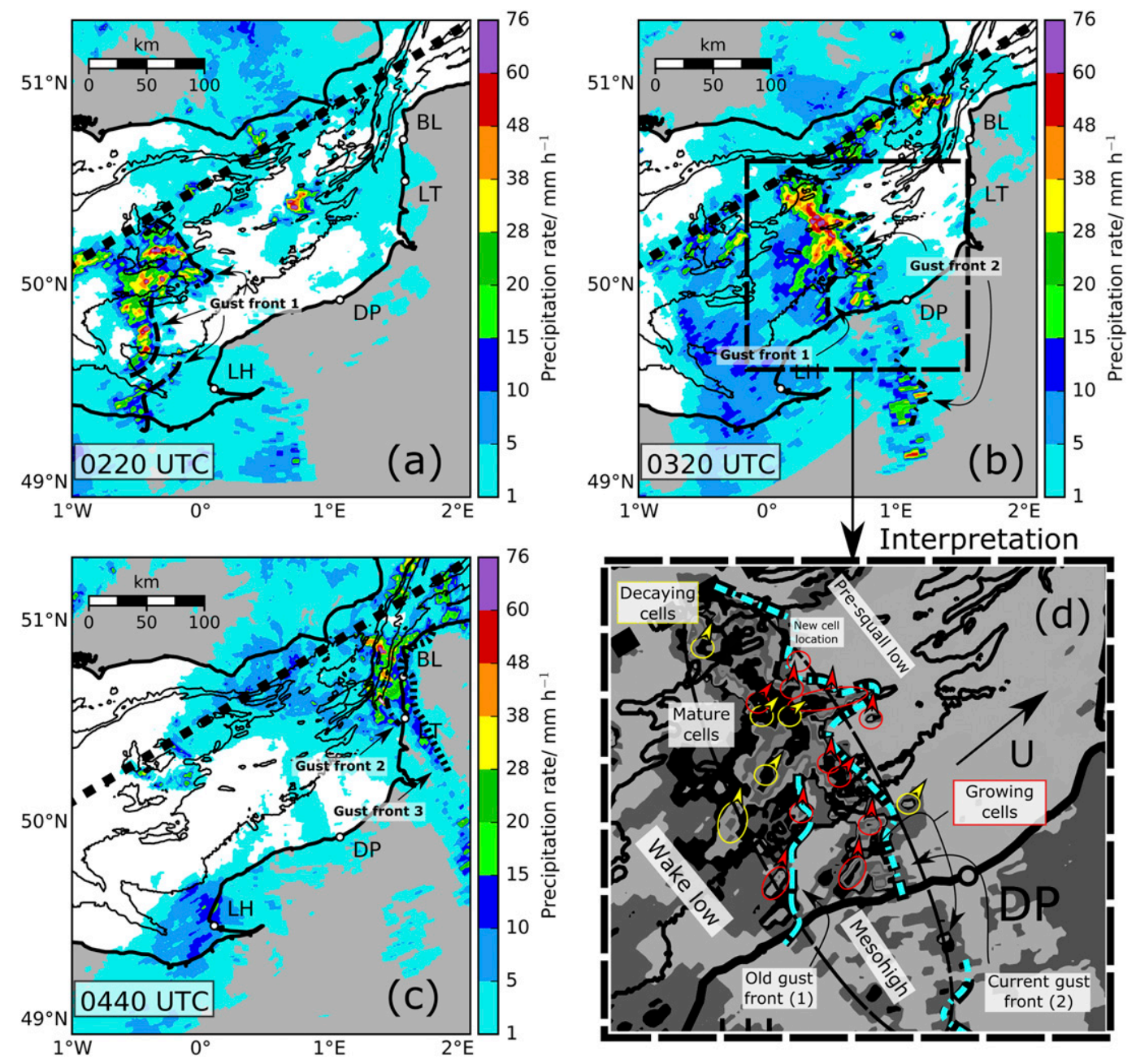

FIG. 3. Composite radar derived precipitation rates $\left(\mathrm{mm} \mathrm{h}^{-1}\right.$ ) are shown for (a) 0220, (b) 0320, and (c) 0440 UTC 23 Jun 2016 in the English Channel (Met Office 2003). Thin black lines indicate where the Froude number is 0.9 and 1.1 with GEBCO 2014 bathymetry and a $19 \mathrm{~m} \mathrm{~s}^{-1}$ atmospheric system speed. The thick, dotted line is the calculated maximum horizontal extent of the convective system. Three gust fronts are indicated. Gust front 1 is long-dashed, gust front 2 is dot-dashed, and gust front 3 is dotted. (d) The interpretation is shown. Yellow circles indicate a decaying cell, and red circles indicate a strengthening cell. The arrowheads indicate the direction these cells moved between 0315 and 0325 UTC. The gust fronts are shown in cyan. Locations of atmospheric stations at LH, DP, LT, and BL are shown. A $100-\mathrm{km}$ scale is given. Land is shaded gray. Thick black lines are coastlines from the Basemap Python package.

\section{2) CONVECTIVE SYSTEM VELOCITY}

By assuming equilibrium between hydrostatic and atmospheric forces (e.g., inverted barometer), calculations suggest that this atmospheric forcing would have only produced a $0.04 \mathrm{~m}$ high wave. Therefore, if the observed wave $(0.70 \mathrm{~m})$ were produced by this convective system, it would have needed amplification mechanisms. This may have happened if the speed of the atmospheric system moved at resonant speed. To determine whether external resonance could have occurred, first we calculated the speed of the convective system using two-dimensional cross correlation of radar-derived precipitation.
Two-dimensional cross correlation has been previously used to estimate meteotsunami forcing velocity with satellite images of cloud tops (Belušić and Mahović 2009) and radar reflectivity (Wertman et al. 2014). Here, cross correlation was used on the radar-derived precipitation fields, which should have provided more representative velocities compared to cloud tops. We took the displacement required for the maximum cross correlation to calculate the velocity of the convective system between time steps. Following Wertman et al. (2014), multiple time steps were used $(5,10,15,20$, and $30 \mathrm{~min})$ between 0200 and 0400 UTC. However, precautions were taken to remove effects of individual cells. Here, a binary signal 

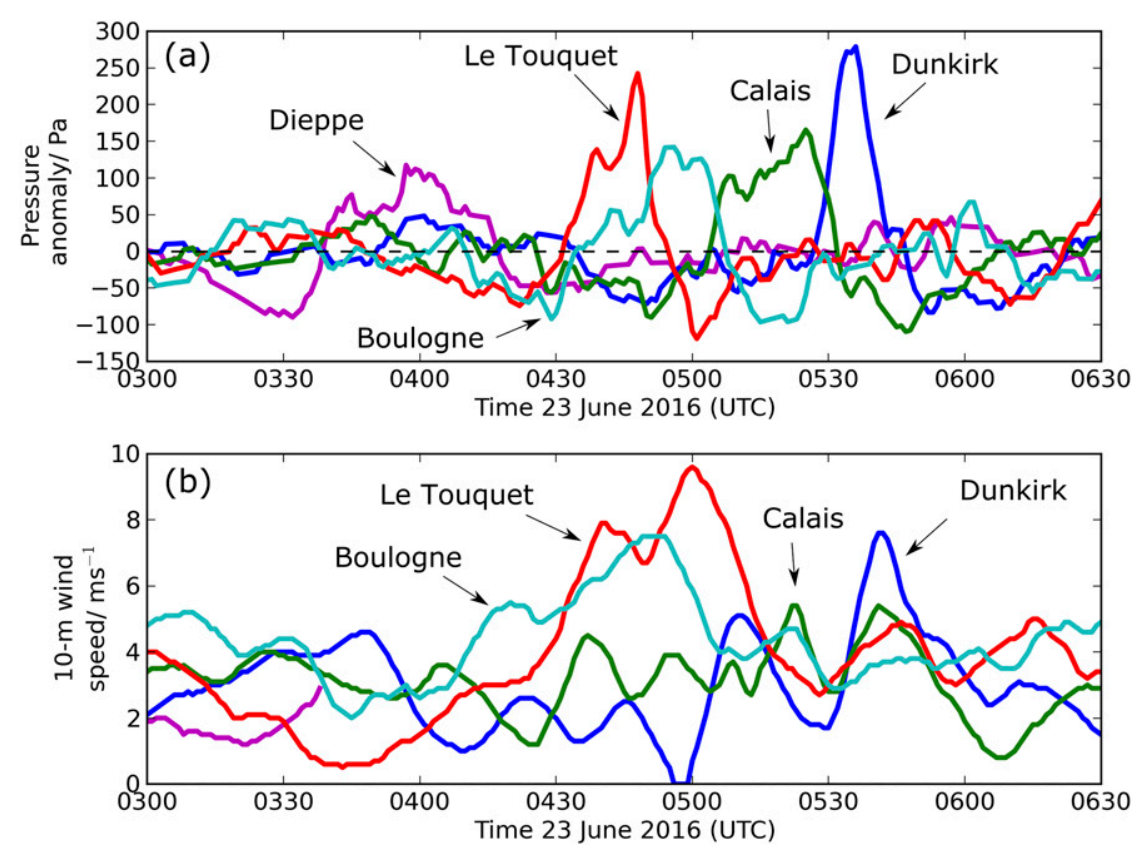

FIG. 4. High-pass-filtered atmospheric observations at Dieppe (purple), Le Touquet (red), Boulogne (cyan), Calais (green), and Dunkirk (blue). (a) The 2-h cutoff high-pass-filtered air pressure time series. (b) Average 10-m wind speed over 10-min windows. Pressure and wind speed sampled once per minute.

was created, equaling 1 when the precipitation rate was greater than a rain-rate threshold and 0 when the rate was less than the threshold. A range of time steps and thresholds on the two-dimensional cross correlation allowed analysis of convective system velocity to chosen parameters and the best range of parameters to be chosen.

When calculating convective system velocity, we assumed straight line motion. With 10-min time steps and a $15 \mathrm{~mm} \mathrm{~h}^{-1}$ threshold, the convective system velocity was estimated as $19 \pm 2 \mathrm{~m} \mathrm{~s}^{-1}$ (all errors here given to $1 \sigma$ ) at a bearing of $35^{\circ} \pm 3^{\circ}$. The speed decreased with larger time steps, from $20 \pm 2 \mathrm{~m} \mathrm{~s}^{-1}$ at $5 \mathrm{~min}$ time steps to $18 \pm 1 \mathrm{~m} \mathrm{~s}^{-1}$ at 20-min time steps. The system's direction of movement was more poorly defined, changing from $21^{\circ} \pm 4^{\circ}$ (more northward) to $47^{\circ} \pm 8^{\circ}$ (more eastward) between 5- and 20-min time steps. Nevertheless, the speed remained consistently between 17 and $22 \mathrm{~m} \mathrm{~s}^{-1}$.

The cross-correlation results were related to the movement of the whole convective system and individual storm cells. Figure 3 shows that three individual gust fronts were identified as the convective system propagated. We identified the gust front as the leading edge of precipitation, which coincided with higher $10-\mathrm{m}$ wind observations. New gust fronts were identified when a new line of cells were generated ahead of, and disconnected from, previous gust fronts. A gust front that generated new convective cells was a form of discrete propagation and produced unreasonably large velocities at certain time steps, which were subsequently removed. More northward velocities were produced at shorter time steps and higher thresholds and explained by storm cell motion that was more northward than the convective system motion (Fig. 3d). This was because individual cells were shorter-lived and produced more intense precipitation than the convective system. Multiple analyses of convective system components were necessary to correctly interpret cross-correlation velocities.

To check that the two-dimensional cross-correlation velocity estimates were reasonable, the average 500-hPa wind velocity from NCEP-NCAR Reanalysis 1 (Kalnay et al. 1996) was calculated within $2.5^{\circ} \mathrm{W}-2.5^{\circ} \mathrm{E}, 47.5^{\circ}-$ $52.5^{\circ} \mathrm{N}$ at $0600 \mathrm{UTC}$. The $500-\mathrm{hPa}$ wind speed is correlated to meteotsunami generation (Vilibić and Šepić 2017), and the speed of convective systems are often near the midtropospheric wind speed (Markowski and Richardson 2011). The reanalysis data showed $22 \pm$ $2 \mathrm{~m} \mathrm{~s}^{-1}$ and northeastward $\left(40^{\circ} \pm 1^{\circ}\right)$ wind velocities. Taking into account both the longer, 20-min time-step cross-correlation analysis at $15 \mathrm{~mm} \mathrm{~h}^{-1}$ cut-offs and the NCEP reanalysis wind speed, the system velocity was about $19 \mathrm{~m} \mathrm{~s}^{-1}$ at a bearing of $45^{\circ}$.

\section{c. Analysis of observations}

Given a forcing speed, possible external resonance mechanisms were examined. When the Froude number (Fr; atmospheric forcing speed divided by wave speed) was between 0.9 and 1.1 , we considered that external 
resonance was possible (Vilibić 2008). We used the edge wave speed $c_{\text {edge }}$ to determine the Greenspan resonance possibility (Greenspan 1956). The edge wave speed of a tsunami-period wave on a constant slope is

$$
c_{\text {edge }}=\frac{g T_{\text {wave }}}{2 \pi} \tan [\beta(2 n+1)],
$$

where $g$ is gravitational acceleration $\left(9.81 \mathrm{~m} \mathrm{~s}^{-2}\right), T_{\text {wave }}$ is wave period, $\beta$ is bathymetric slope, and $n$ is edge wave mode (corresponding to the number of times the trapped edge wave crosses the still water level in the crosspropagation direction).

Taking transects from near Dieppe across the channel, the bathymetry was approximated by two slopes. The first slope was steeper, decreasing by $21 \mathrm{~m}$ between 0 and $6 \mathrm{~km}$ from the coastline $(\beta \approx 0.0035)$. The second slope was shallower, decreasing by $20 \mathrm{~m}$ between 6 and $60 \mathrm{~km}$ from the coastline $(\beta \approx 0.0004)$. This change in gradient is evident when comparing the 20 - and $40-\mathrm{m}$ contours near Dieppe (Fig. 1). From Eq. (1) and the observed wave period, the edge wave speed was $1.3 \mathrm{~m} \mathrm{~s}^{-1}$ on the shallow slope and $11.6 \mathrm{~m} \mathrm{~s}^{-1}$ on the steep slope. These edge wave speeds were more than $10 \%$ slower than the alongshore forcing speed, meaning that Greenspan resonance was not possible.

Next, we investigated Proudman resonance. Proudman resonance occurs when the atmospheric system speed $U$ is near the shallow-water wave speed $c$ (Proudman 1929). The shallow-water wave speed is proportional to water depth $H$ and is given by

$$
c=\sqrt{g H} .
$$

Using a forcing speed of $U=19 \mathrm{~m} \mathrm{~s}^{-1}$ and depths at mean sea level (Fig. 1), a Froude number between 0.9 and 1.1 was calculated in the location of the precipitation at 0320 UTC (Fig. 3). Therefore, Proudman resonance was possible. This result was also retained when accounting for tides. Assuming that the shallowwater wave speed changes with tidal elevation $H_{T}$ and ocean currents in the wave propagation direction $V_{T}$ (Choi et al. 2014), the shallow-water wave speed is approximately

$$
c \approx \sqrt{g\left(H+H_{T}\right)}+V_{T} .
$$

Including tidal elevation and current estimates $\left(H_{T}=\right.$ $-0.5 \mathrm{~m} ; V_{T}=-1 \mathrm{~m} \mathrm{~s}^{-1}$ ) showed that Proudman resonance was possible, but the Proudman resonant region would have moved away from the coastline (cf. regions in Fig. 1).

We then analyzed expected wave growth under Proudman resonance. Churchill et al. (1995) derive the following relationship for a linear shallow-water wave $\eta$, trapped underneath a constant amplitude, moving forcing assuming one-dimensional, frictionless propagation without planetary rotation:

$$
\eta=\frac{x}{2 \rho g}\left(-\frac{\partial p}{\partial x}+\frac{\tau_{s}}{H_{\mathrm{Pr}}}\right),
$$

where $x$ is distance in the propagation direction, $\rho$ is water density, $p$ is atmospheric pressure, $\tau_{s}$ is surface wind stress, and $H_{\mathrm{Pr}}$ is the depth at which Fr is 1 . If a sea surface perturbation were amplified by Proudman resonance, it would have grown linearly with distance and been a linear combination of the pressure and wind stress forcing. Simply, the sea surface perturbation would have been the combined pressure induced perturbation $\eta_{p}$ and wind stress-induced perturbation $\eta_{\tau}$ :

$$
\eta=\eta_{p}+\eta_{\tau}
$$

For a pressure field approximated by an advecting sinusoid, with maximum pressure change $\Delta p$ and wavelength $\lambda$, the maximum pressure induced perturbation is

$$
\eta_{p}=\pi \frac{\Delta p}{\rho g} \frac{x}{\lambda}
$$

and using approximations from observations, a 40-km wavelength, and 200-Pa pressure perturbation would have produced a wave height of $0.31 \mathrm{~m}$ after moving $200 \mathrm{~km}$ across the English Channel toward Boulogne.

To calculate the wave induced by wind stress, wind stress was parameterized as $\rho_{a} C_{a} U_{10}^{2}\left[\rho_{a}\right.$ is air density $\left(1 \mathrm{~kg} \mathrm{~m}^{-3}\right), C_{a}$ is the drag coefficient of air on the water surface, and $U_{10}$ is the $10-\mathrm{m}$ wind speed]. The perturbation $\eta_{\tau}$ was then approximated by

$$
\eta_{\tau} \approx \frac{1}{2} \frac{\rho_{a} C_{a} U_{10}^{2}}{\rho g} \frac{x}{H_{\mathrm{Pr}}} .
$$

Inputting a $10 \mathrm{~m} \mathrm{~s}^{-1} 10-\mathrm{m}$ wind speed, a drag coefficient of 0.0012 (Large and Pond 1981), and 37-m resonant water depth, then $\eta_{\tau}$ was about $0.03 \mathrm{~m}$. If the wind stress and pressure components of the wave constructively interfered, then the maximum wave height after Proudman resonance would have been $0.34 \mathrm{~m}$.

The maximum wave height at Boulogne was $0.70 \mathrm{~m}$, meaning that 2.1 times more amplification would have been required. From the conservation of wave energy flux, waves grow when moving into shallower water as described by Green's law (Pugh and Woodworth 2014):

$$
\frac{\eta_{1}}{\eta_{0}} \propto\left(\frac{H_{0}}{H_{1}}\right)^{1 / 4} .
$$


A wave with original wave height $\eta_{0}=0.34 \mathrm{~m}$, which was generated in depth $H_{0}=H_{\mathrm{Pr}}=37 \mathrm{~m}$, and shoaled to depth $H_{1}=5 \mathrm{~m}$ (approximate water depth at Boulogne in Fig. 2), would have a resultant wave height $\eta_{1}=0.56 \mathrm{~m}$. The wave height may have then further amplified through refraction, but this is difficult to quantify without numerical modeling.

This analysis has provided some evidence toward the generation mechanisms of the observed wave. It has suggested that atmospheric pressure was the primary forcing $(91 \%)$ and wind stress was secondary $(9 \%)$, external resonance occurred through Proudman resonance, and shoaling produced further amplification. However, idealized analysis has only partly explained wave heights at Boulogne, rather than provide a deeper understanding of the link between generation mechanisms and the observed meteotsunami. Numerical models could provide this understanding, alongside stronger evidence for wave growth through Proudman resonance, and quantify wave height sensitivity to atmospheric forcing and tides.

\section{Modeling}

\section{a. Telemac}

We used the finite-element ocean model Telemac (Hervouet 2000) to model the wave, which solved the two-dimensional nonlinear shallow-water momentum and continuity equations. Here they are given in twodimensional vector form:

$$
\begin{aligned}
\frac{\partial \mathbf{u}}{\partial t}+\mathbf{u} \cdot \nabla \mathbf{u}+\mathbf{f} \times \mathbf{u}= & -g \nabla \eta-\frac{1}{\rho} \nabla p-\frac{g}{C^{2}} \frac{|\mathbf{u}| \mathbf{u}}{H+\eta} \\
& +C_{a} \frac{\rho_{a}}{\rho} \frac{\left|\mathbf{U}_{10}\right| \mathbf{U}_{10}}{H+\eta}+A_{h} \nabla^{2} \mathbf{u}, \quad \text { and }
\end{aligned}
$$

$\frac{\partial \eta}{\partial t}+\nabla \cdot[\mathbf{u}(H+\eta)]=0$,

where $\mathbf{u}$ is the depth-averaged horizontal velocity vector, $\nabla$ is the horizontal gradient vector, $t$ is time, $C$ is the Chézy coefficient $\left(60 \mathrm{~m}^{1 / 2} \mathrm{~s}^{-1}\right), A_{h}$ is the eddy viscosity $\left(150 \mathrm{~m}^{2} \mathrm{~s}^{-1}\right)$, and $\mathbf{f}$ is the Coriolis parameter, directed vertically upward. With wind in the model, $\mathbf{U}_{10}$ is the $10-\mathrm{m}$ wind vector.

Equations (9) and (10) were solved on a multiscale triangular mesh, generated with Blue Kenue (Canadian Hydraulics Centre 2016), using 30-arc-s bathymetry from General Bathymetric Chart of the Oceans (GEBCO) 2014 (IOC et al. 2003). The mesh node spacing was $500 \mathrm{~m}$ in the eastern English Channel. For all nontidal models, we used 2-s, fully implicit time stepping, and simulations ran for at least $22000 \mathrm{~s}(6.1 \mathrm{~h})$.

\section{b. Atmospheric forcing}

The atmospheric pressure $p$ was prescribed by an analytical forcing function:

$$
p= \begin{cases}p_{t} \frac{\tanh \psi+1}{2} \cos \phi+p_{b}, & \text { if }-\frac{3 \pi}{2} \leq \phi \leq \frac{3 \pi}{2} \\ p_{b}, & \text { otherwise }\end{cases}
$$

The bounds of the argument $\phi=\mathbf{k} \cdot \mathbf{x}-\omega t$ describe a low-high-low pressure pattern, where $\mathbf{k}$ is the wavenumber vector, and $\mathbf{x}$ is the position vector. The $\omega$ is angular frequency, where $\omega=2 \pi / T$ and $T$ is the forcing period. The maximum pressure perturbation $p_{t}$ was prescribed on a 1013-hPa background pressure $p_{b}$.

The geographical extent of the forcing was also parameterized, because the convective system did not extend to the United Kingdom and could not be completely determined from the observations. The end of the convective system was determined as the last $20 \mathrm{~mm} \mathrm{~h}^{-1}$ precipitation rate along the cross-propagation axis at multiple time steps. A linear regression through the end points was used as the extent of the modeled pressure anomaly (thick dashed line in Fig. 3). In Eq. (11), this was given by $\psi=\alpha\left(\Phi-0.386 \Lambda-50.49^{\circ} \mathrm{N}\right)$, where $\Phi=$ latitude, $\Lambda=$ longitude, and $\alpha=1 / 4000 \mathrm{~m}^{-1}$.

The pressure perturbations were modeled using the best estimates provided by the observations, and ensembles were used to account for observational uncertainties. To create the ensemble, we varied four characteristics: forcing speed $U\left(17-22 \mathrm{~m} \mathrm{~s}^{-1}, 1 \mathrm{~m} \mathrm{~s}^{-1}\right.$ increments), forcing direction as a clockwise bearing from north $\theta\left(35^{\circ}-55^{\circ}, 5^{\circ}\right.$ increments), pressure perturbation amplitude $(0.9-1.5 \mathrm{hPa}$, 0.1-hPa increments), and forcing period (30-38 $\mathrm{min}, 1-\mathrm{min}$ increments). The model that we decided was the best estimate of atmospheric observations (not necessarily producing the most accurate wave height simulations) had $19 \mathrm{~m} \mathrm{~s}^{-1}$ forcing speed, $45^{\circ}$ forcing direction, 1 -hPa pressure perturbation amplitude, and 36-min forcing period. The behavior in time for this case is shown in Fig. 5, and contours of $p$ can be seen in Fig. 6 .

\section{c. Best-estimate model}

A time series of the atmospheric pressure forcing with the best-estimate parameters is shown in Fig. 5. The observed pressure anomaly was 10-60-min bandpass filtered, removing the long-term synoptic signal and high-frequency noise. The model and observation timings were aligned such that the time of modeled high pressure perturbation coincided with the time of maximum pressure perturbation observed at Boulogne. At Le Touquet and Boulogne, the modeled and observed 

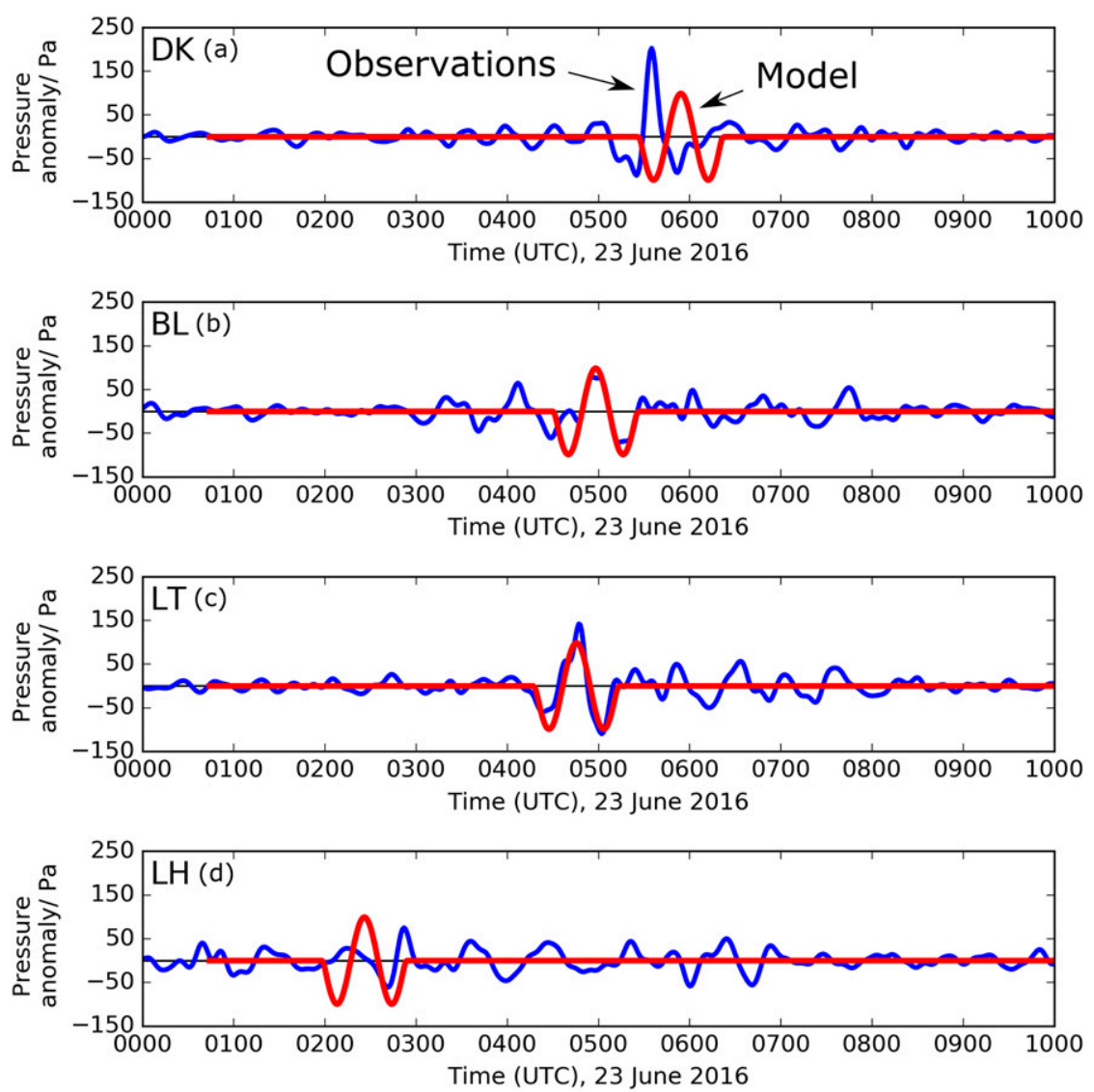

FIG. 5. Red: modeled pressure anomaly (hPa) for the model $U=19 \mathrm{~m} \mathrm{~s}^{-1}, \theta=45^{\circ}$, $T=36 \mathrm{~min}$, and $p_{t}=1 \mathrm{hPa}$. Blue: 10-60-min bandpass-filtered pressure (hPa). (a) Dunkirk, (b) Boulogne, (c) Le Touquet, and (d) Le Havre.

timings and pressure amplitudes were well represented. At Dunkirk, to the northeast, the modeled pressure was much lower amplitude and out of phase with observations. Also, at Le Havre the pressure anomaly was poorly approximated because the convective system approached from a different angle than was modeled. However, in the Proudman-resonant region there was good agreement between the model and the observed pressures, as well as the calculated velocities of radarderived precipitation fields.

From the best-estimate model forcing, the sea surface height fields (Fig. 6) show that two waves were initially created by the pressure system. The primary forced wave grew in the center of the English Channel (Figs. 6a-c). There was also a coastal wave (dashed box in Figs. 6b,c), which also grew as it propagated eastward along the French coastline to similar amplitudes as the directly forced wave. At Dieppe it was this coastal wave that was recorded by the tide gauge (Fig. 7), which was followed by reflections from the French coastline. At Boulogne the directly forced wave arrived first, which was followed by the coastal wave up the French coastline and reflections from the U.K. coastline. At Le Havre the first wave to arrive was a directly forced wave underneath the pressure disturbance, and then reflections arrived later. At Newhaven the first wave to arrive was freely propagating away from the pressure disturbance. Reflections were also modeled from the French coastline back toward the United Kingdom (Fig. 6d). In further analysis of the meteotsunami, different components of the wave are referred to as free, directly forced, coastal, and reflected.

Examining the relationship between pressure disturbance and water level, the directly forced wave was proportional to the negative of the pressure gradient (cf. pressure and sea level disturbance in Fig. 6). This behavior is predicted by Eq. (4), implying Proudman resonance. The directly forced wave also grew as it propagated along the Channel, in depths appropriate for Proudman resonance $(0.9 \leq \mathrm{Fr} \leq 1.1)$. Using Eq. (6), under perfect Proudman resonance, this wave should have grown by $0.10 \mathrm{~m}$ between 95 and $155 \mathrm{~min}$. The model simulated $0.08-\mathrm{m}$ wave growth over this time $(0.12-0.20 \mathrm{~m})$. The directly forced wave grew within 

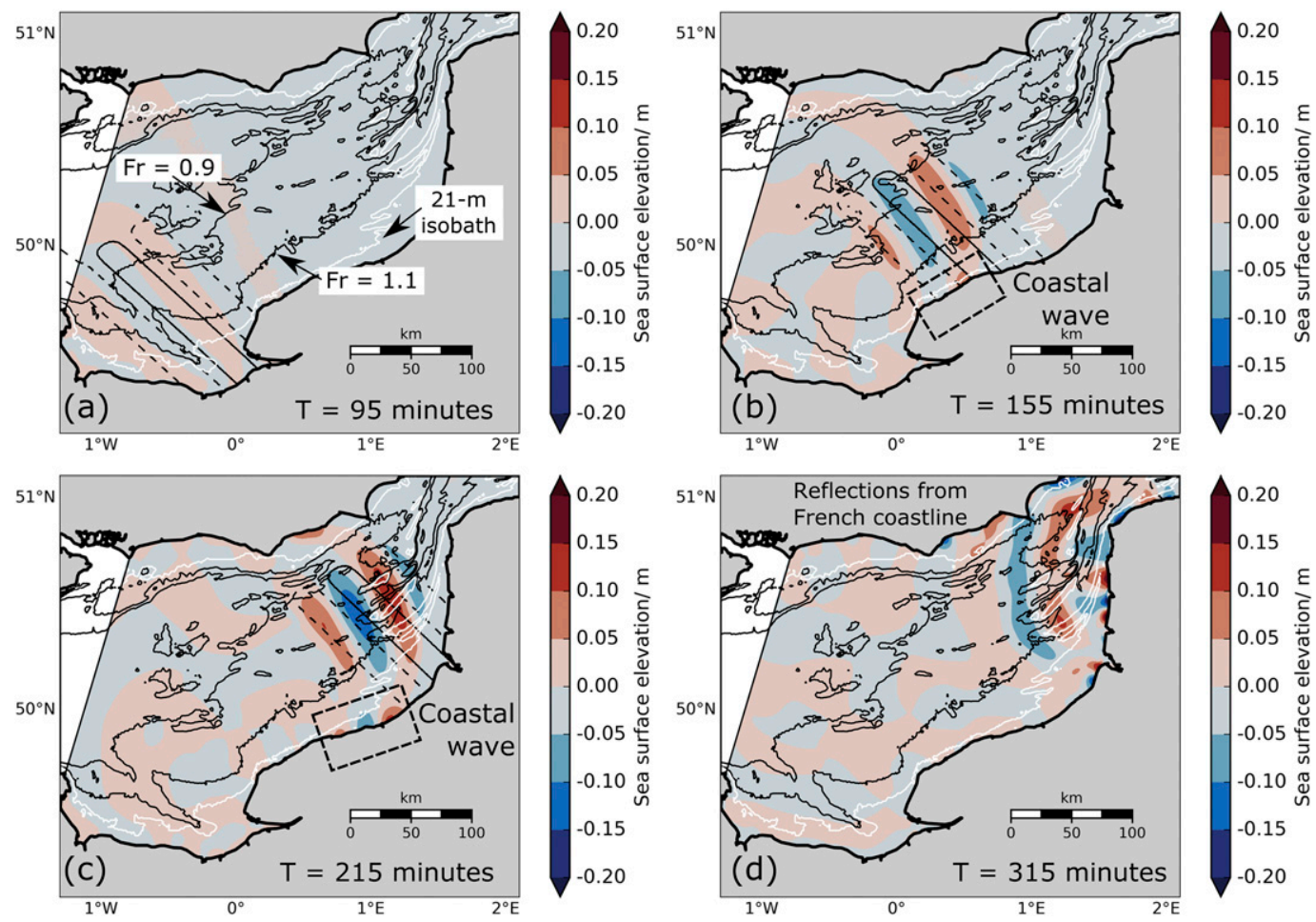

FIG. 6. Modeled sea level elevation (colors) at (a) 95, (b) 155, (c) 215 and (d) 315 min into the best-estimate simulation. Froude number contours at 0.9 and 1.1 from unaltered GEBCO bathymetry are shown as thin black lines. The western open boundary is shown in black. The sea level pressure is shown in black solid $(+0.5 \mathrm{hPa})$ and dashed $(-0.5 \mathrm{hPa})$ lines. All panels give interpretation of the modeled sea level elevation, with the coastal wave in a dashed black box in (b) and (c). The $21-\mathrm{m}$ isobath is shown as a thin white line. Note the color saturates at +0.2 and $-0.2 \mathrm{~m}$.

$20 \%$ of theoretical calculations of wave amplitude, consistent with the predictions of Proudman resonance. This is the strongest available evidence that this was the amplification mechanism for the directly forced wave.

This wave was not damaging, and compared to concurrent wind waves it had a similar wave energy flux density. When the wave uncoupled from the atmospheric forcing, the energy flux density of the directly forced wave was about $3.4 \mathrm{~kW} \mathrm{~m}^{-1}$, which is similar to the energy flux density of 0.4-m-high, 9-s period wind waves measured at the Greenwich Lightship Buoy $\left(1.4 \mathrm{~kW} \mathrm{~m}^{-1}\right)$. However, meteotsunamis may be more damaging than this wave flux density suggests. Long, coherent wave crests mean that a relatively large total energy flux is available for focusing. Here, $340 \mathrm{MW}$ was available for focusing from the $100-\mathrm{km}$ crest. Nonetheless, this meteotsunami was not damaging, and the simulations did not suggest considerable wave energy focusing through refraction in the English Channel.

The coastal wave growth was further investigated through idealized numerical models, because its growth mechanism was unclear and Greenspan resonance was previously discounted through Froude number arguments. In these models the bathymetry was assigned the previously approximated shallow and steep slopes near the French coastline, and a moving sinusoidal pressure forcing was prescribed (Fig. 8). This idealized model reproduced the coastal wave under baseline slope approximations (Fig. 8a). First, we changed the gradient of the steep slope between 0.002 and 0.01 , and a coastal wave with a similar amplitude to the forced wave was modeled (Figs. 8e,f). The coastal wave was also reproduced when the pressure forcing was cut off at $y=6 \mathrm{~km}$, showing that it was not produced by direct forcing (Fig. 8b). We then altered the shallow slope section such that Proudman resonance could not produce a large forced wave (Fig. 8g). If the coastal wave were directly forced by the pressure disturbance over the steep slope, this should not affect the coastal wave amplitude. However, the coastal wave magnitude also decreased to the amplitude of the Proudman resonance forced wave. Therefore, the coastal wave was directly related to the forced wave generated in the English Channel by Proudman resonance and appeared to be separate because it was heavily refracted by the steep slope.

The arrival times and periods for both the coastal wave and directly forced wave were modeled well at Dieppe and Boulogne. The modeled arrival time at 

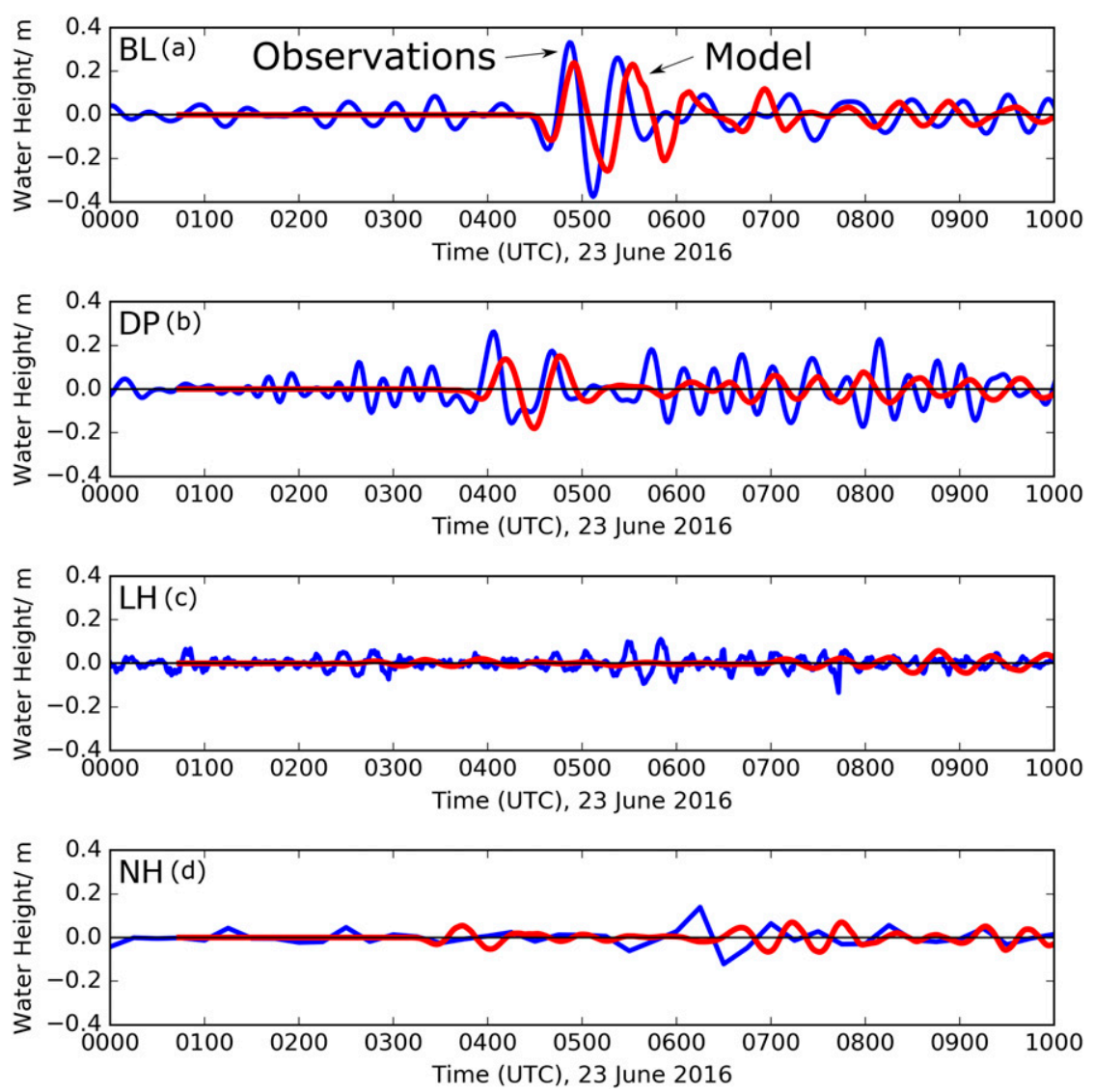

FIG. 7. Red: modeled sea surface elevation at tide gauges for the model $U=19 \mathrm{~m} \mathrm{~s}^{-1}, \theta=45^{\circ}$, $T=36 \mathrm{~min}$, and $p_{t}=1 \mathrm{hPa}$. Blue: 10-60-min bandpass-filtered observations. (a) Boulogne, (b) Dieppe, (c) Le Havre, and (d) Newhaven.

Boulogne, 0449 UTC, was only 2 min behind the observed arrival time, 0447 UTC (Fig. 7). The arrival time at Dieppe was more poorly recreated, which was measured as 0358 UTC and modeled as 0405 UTC, a lag in the model of $7 \mathrm{~min}$. The difference in arrival times between the waves at Boulogne and Dieppe gave a 5-min relative difference of modeled arrival times ( $44 \mathrm{~min}$ ) compared to observations $(49 \mathrm{~min})$. The dominant period of the modeled wave is approximately $34-39 \mathrm{~min}$ at Boulogne and Dieppe, which is approximately $5 \mathrm{~min}$ longer than observed. The wave traveled faster in the model between Dieppe and Boulogne by a few minutes, and the period of the wave was longer than expected.

The maximum wave heights, given by the maximum difference between consecutive peaks and troughs, were simulated to within tens of centimeters. At Boulogne, a 0.70-m wave was observed, compared to the best-estimate model $0.50-\mathrm{m}$ wave height (29\% underestimate). At Dieppe, a 0.43-m wave was observed, compared to the bestestimate model 0.33 -m wave height ( $23 \%$ underestimate). The model did not produce a large wave at Le Havre, but there were no discernible observations here either.
The model was poorer at representing sea surface elevation at Newhaven than at other locations. The bestestimate model produced a perturbation at Newhaven due to the initial movement of the convective system over the English Channel, which was not discernible in the observations. Also, the first peak of the reflected wave at Newhaven was about $30 \mathrm{~min}$ after the maximum observed peak, and the largest modeled peak was about $60 \mathrm{~min}$ after the maximum observed peak. However, the amplitudes of later perturbations were similar to observations (Fig. 7). We accept the model limitations at Newhaven as the result of forcing simplifications, which did not include other storms that occurred prior to, and after, the synthetically modeled convective system (cf. Fig. 3 and Fig. 6). These other storms could have produced forced waves $(0.06 \mathrm{~m}$ high $)$ that shoaled up to $0.10-0.14 \mathrm{~m}$ high at the Newhaven coastline $\left[\mathrm{Fr} \approx 0.85, H_{0} \approx 50 \mathrm{~m}, H_{1} \approx 1 \mathrm{~m}\right.$, $\Delta P \approx \pm 0.75 \mathrm{hPa}$, and $\left.\eta_{0}=-\Delta P / \rho g\left(1-\mathrm{Fr}^{2}\right)\right]$. Furthermore, the simplicity of the larger convective system would have affected both the initial free wave and the initial angles of freely reflected waves at the French coastline (Vennell 2010). Nonetheless, it is difficult to 

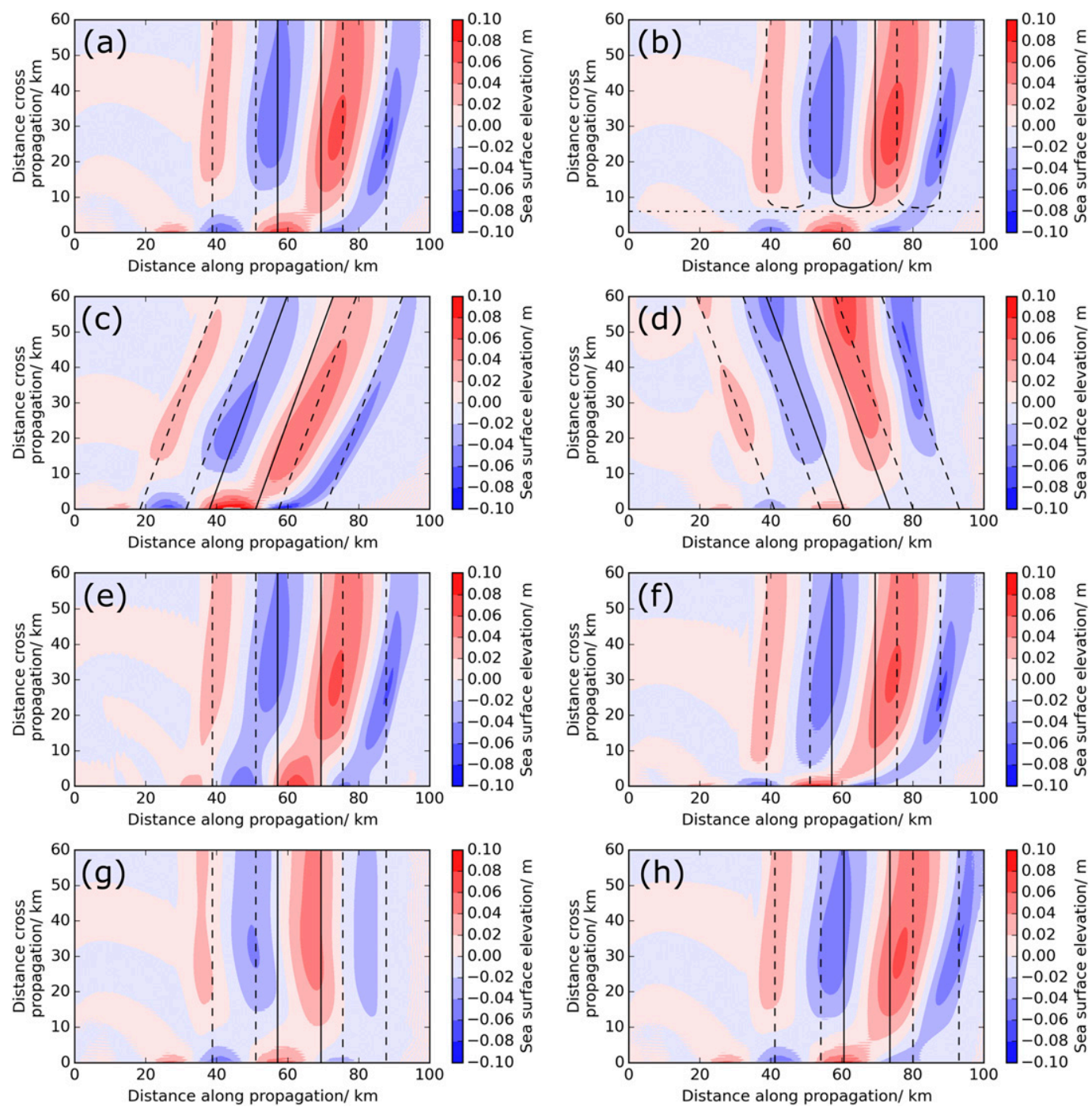

FIG. 8. Idealized simulations investigating coastal wave generation mechanism. Colors range from -0.1 to $+0.1 \mathrm{~m}$. Black contours are +0.5 - and -0.5 -hPa pressure anomalies. (a) Base line model. Infinite cross-propagation length, $U=17 \mathrm{~m} \mathrm{~s}^{-1}$, normal bathymetry $\beta_{0}=0.0035, \beta_{1}=0.00037$. (b) Pressure cut off in the cross propagation direction at $6 \mathrm{~km}$ (dot-dashed black line). (c) Moving toward the coastline, (d) moving away from coastline, (e) steep slope made steeper $\left(\beta_{0}=0.01\right)$, (f) steep slope made shallower $\left(\beta_{0}=0.002\right)$, (g) shallow slope between 6 and $60 \mathrm{~km}$ made flat $\left(\beta_{1}=0\right)$, and (h) forcing speed is $18 \mathrm{~m} \mathrm{~s}^{-1}$.

compare the model output with sea surface observations sampled at 15 -min intervals.

\section{d. Atmospheric forcing ensembles}

To understand the sensitivities of the predictions of meteotsunami height and arrival times, we created ensembles by varying forcing velocity, amplitude of the pressure perturbations, and forcing period.

\section{1) FORCING VELOCITY}

Model results from forcing speeds at 17, 19, and $21 \mathrm{~m} \mathrm{~s}^{-1}$ across angles $35^{\circ}-55^{\circ}$ are shown in Fig. 9. The arrival time difference between the wave arriving in
Boulogne and Dieppe was mostly dependent on the propagation time of the atmospheric forcing. The average of the relative differences in arrival times was 53, 42 , and $34 \mathrm{~min}$ at 17,19 , and $21 \mathrm{~m} \mathrm{~s}^{-1}$, respectively. The faster the forcing speed, the smaller the modeled arrival time difference at each location. The relative arrival time of the wave was controlled by the forcing speed because the directly forced wave was trapped underneath the forcing. The modeled arrival time difference between Dieppe and Boulogne was 5 min too short, suggesting that the atmospheric system speed may have been slower than our best estimate but falls within error estimates $\left(19 \pm 2 \mathrm{~m} \mathrm{~s}^{-1}\right)$. 
Dieppe
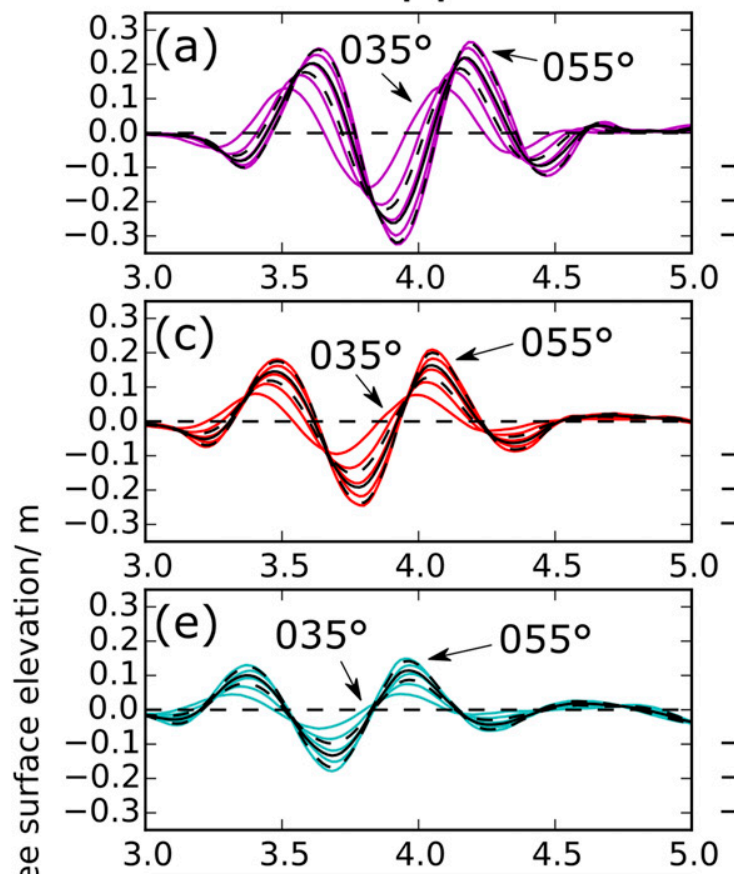

는
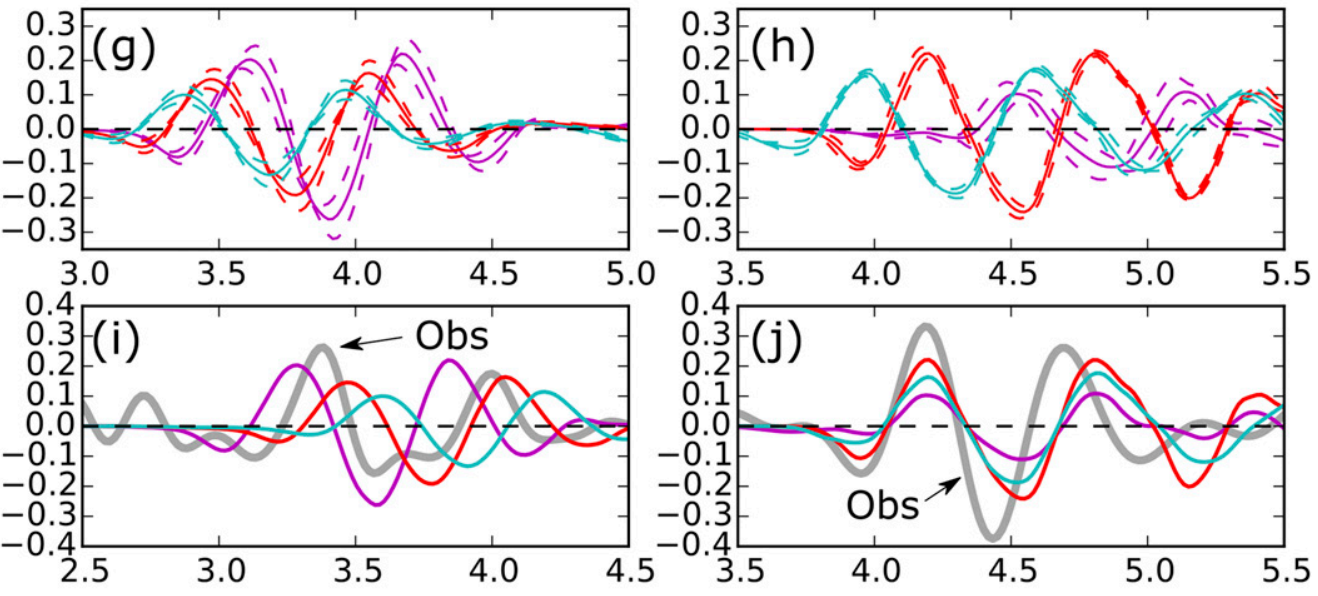

Time from model start/ hours

FIG. 9. Sea surface elevation sensitivity to forcing angles and speeds. Model runs at each angle $\left(35^{\circ}-55^{\circ}\right)$ are shown (a),(b) at $17 \mathrm{~m} \mathrm{~s}^{-1}$ in purple, (c),(d) at $19 \mathrm{~m} \mathrm{~s}^{-1}$ in red, and (e),(f) at $21 \mathrm{~m} \mathrm{~s}^{-1}$ in cyan. The model results (left) from Dieppe and (right) from Boulogne. Each individual colored line in (a)-(f) represents an individual simulation at a specific forcing speed and angle. The solid black line is the mean across individual models, and the dashed black lines are one standard deviation from the mean. $(\mathrm{g}),(\mathrm{h})$ Comparison of the averages and standard deviations from 17, 19, and $21 \mathrm{~m} \mathrm{~s}^{-1}$ at Dieppe and Boulogne in respective colors. (i),(j) Comparison of the averages from each speed with the bandpass-filtered observations in gray. In (i) and (j), simulation timings and observation timings are aligned with respect to the average of $U=19 \mathrm{~m} \mathrm{~s}^{-1}$ simulations. Note the change in scale and time shift in (i) and (j).

Figure 9 shows that the modeled maximum wave heights varied with both forcing speeds and angles, but were mainly dependent on forcing speeds. Across 30 simulations, maximum wave heights at Boulogne were consistently obtained at $19 \mathrm{~m} \mathrm{~s}^{-1}$, with greater than $0.4-\mathrm{m}$ maximum wave heights averages obtained between 19 and $20 \mathrm{~m} \mathrm{~s}^{-1}$. At Boulogne, wave height was relatively insensitive to forcing angle when the forcing speed was $19 \mathrm{~m} \mathrm{~s}^{-1}$, ranging from 0.43 to $0.52 \mathrm{~m}(0.48 \mathrm{~m} \pm 9.5 \%)$; the largest wave heights were achieved at forcing angles between $40^{\circ}$ and $50^{\circ}$ and decreased away from these angles. Wave height was more sensitive to angle when the speed was $17 \mathrm{~m} \mathrm{~s}^{-1}$, with maximum wave heights between 0.20 and $0.43 \mathrm{~m}(0.32 \mathrm{~m} \pm 36 \%)$ at Boulogne. Dieppe was 


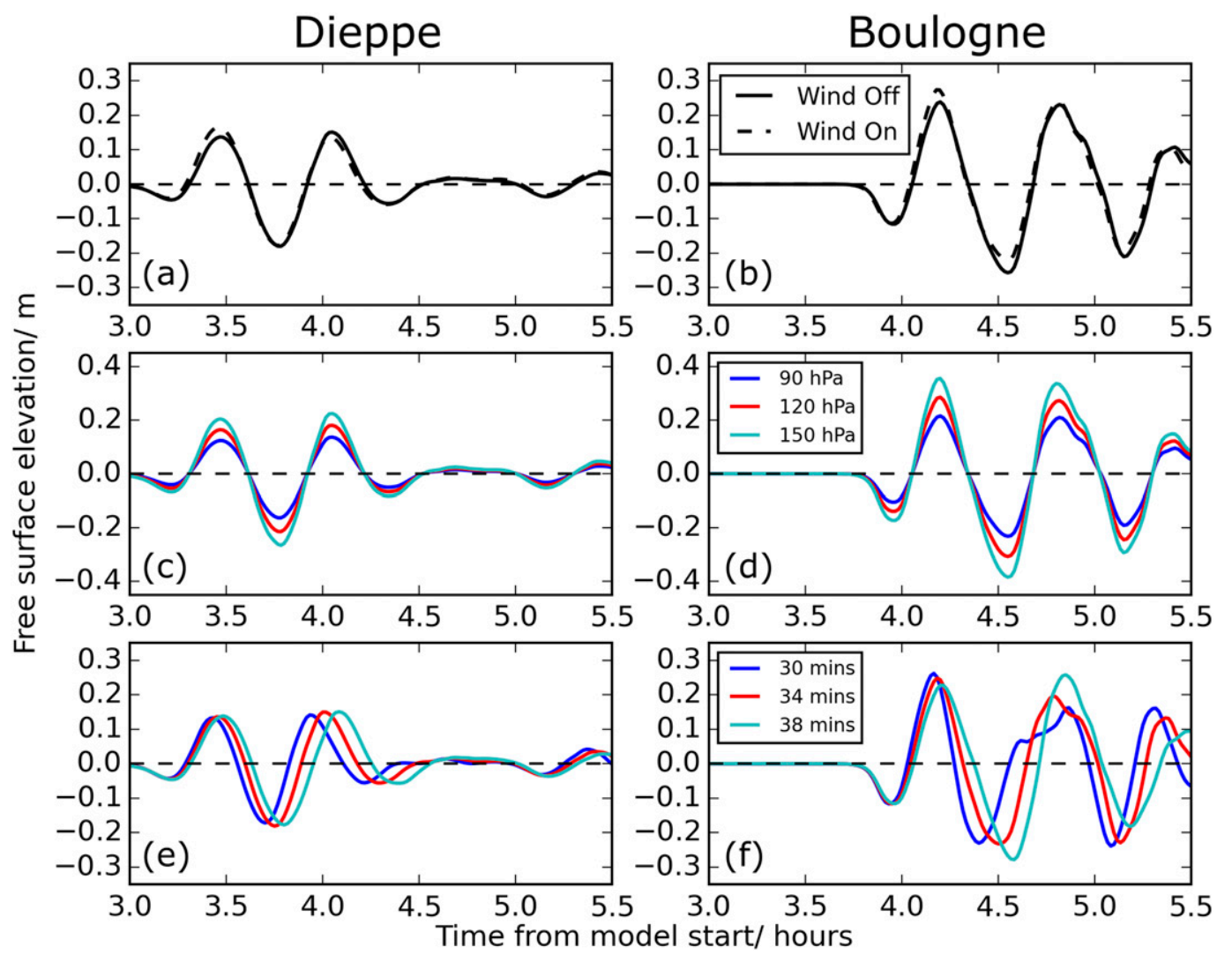

FIG. 10. Sea surface elevation sensitivity to wind, amplitude, and period. (left) Dieppe and (right) Boulogne. (a),(b) The $10 \mathrm{~m} \mathrm{~s}^{-1}$ wind component on (solid line) and off (dashed) where $U=19 \mathrm{~m} \mathrm{~s}^{-1}, \theta=45^{\circ}, T=36 \mathrm{~min}$, and $p_{t}=1 \mathrm{hPa}$. (c),(d) Varying $p_{t}$ between 0.9 (blue), 1.2 (red), and $1.5 \mathrm{hPa}$ (cyan), where $U=19 \mathrm{~m} \mathrm{~s}^{-1}, \theta=45^{\circ}$, and $T=36$ mins. (e),(f) Varying $T$ between 30 (blue), 34 (red), and $38 \min$ (cyan), where $U=19 \mathrm{~m} \mathrm{~s}^{-1}, \theta=45^{\circ}$, and $p_{t}=1 \mathrm{hPa}$. Note the change in $y$-axis scale for (c) and (d).

more sensitive to forcing angle than Boulogne, with maximum wave heights between 0.19 and $0.48 \mathrm{~m}(0.34 \pm$ $44 \%)$ at $19 \mathrm{~m} \mathrm{~s}^{-1}$ and 0.29 and $0.59 \mathrm{~m}(0.44 \mathrm{~m} \pm 34 \%)$ at $17 \mathrm{~m} \mathrm{~s}^{-1}$. At Dieppe wave heights were largest at $55^{\circ}$ and decreased with more northward forcing angles.

The wave height at Dieppe decreased as the forcing moved faster and more northward (Fig. 9). Again, idealized models showed wave height sensitivity to forcing velocity; forcings moving toward the coastline produced larger waves (Fig. 8c) and forcings moving away from the coastline produced smaller waves (Fig. 8d). Also, because the Proudman resonant region was further from the coastline for faster forcings, smaller wave heights should be expected (Fig. 8h).

Our sensitivity analysis in the English Channel also revealed that a forcing speed between 18 and $19 \mathrm{~m} \mathrm{~s}^{-1}$ would have improved arrival times, without degrading wave heights, at Boulogne and Dieppe (Figs. 9i,j). The cause of arrival time error was probably because the atmospheric forcing velocity was treated as a constant velocity, whereas observations showed more complicated system movement (Fig. 3). Nevertheless, the accuracy of modeled arrival times, period, and wave height give confidence that the convective system moved at Proudman resonant velocity and produced the observed meteotsunami.

\section{2) Pressure Perturbation Amplitude}

Increasing the pressure perturbation amplitude increased the maximum wave height. A $0.9-\mathrm{hPa}$ forcing produced a $0.45-\mathrm{m}$ wave at Boulogne, and using a $1.5-\mathrm{hPa}$ forcing produced a 0.74-m wave (Figs. 10c,d). At Dieppe, a $0.9-\mathrm{hPa}$ forcing produced a $0.30-\mathrm{m}$ wave, and a $1.5-\mathrm{hPa}$ forcing produced a $0.49-\mathrm{m}$ wave. Linear regression of the maximum wave heights at Boulogne and Dieppe from 0.9-1.5-hPa forcings, revealed a strongly linear relationship between pressure amplitude and maximum wave height. This linear relationship is a well-known result.

\section{3) FORCING PERIOD}

Changing the forcing period created more complicated resultant behavior in the modeled meteotsunami than altering the amplitude of the forcing (Figs. 10e,f). 
There was some expected behavior in the absence of seiching. A longer period forcing generated a proportionally longer period meteotsunami, and all models with 30-38-min period forcings agreed with the shape of the meteotsunami waveform at Dieppe. However, at Boulogne, the modeled meteotsunami maximum wave heights behaved unpredictably after the first trough. Furthermore, the largest modeled wave was from the shortest period forcing at Boulogne, whereas at Dieppe the largest modeled wave was from the longest period forcing.

This sensitivity was from wave superposition of the direct forced wave at Boulogne and the coastal wave traveling up the coastline from Dieppe. From these results, hazard assessments should use various forcing periods.

\section{e. Wind}

When including wind, the 10-m wind velocity was modeled as two $10 \mathrm{~m} \mathrm{~s}^{-1}$ amplitude half-sinusoids with the same period as the pressure disturbance. The two wind maxima were aligned with where the pressure disturbance was $0 \mathrm{hPa}$, between the simulated mesohigh and mesolows, representing observations at Le Touquet (Fig. 4). The wind vector field, which moved at the same velocity as $p$, was prescribed:

$$
\mathbf{U}_{10}=U_{10} \cos \chi \hat{\mathbf{i}}+U_{10} \sin \chi \hat{\mathbf{j}},
$$

where $\chi=45^{\circ}$ (northeastward 10 -m winds), $\hat{\mathbf{i}}$ and $\hat{\mathbf{j}}$ were unit vectors in the eastward and northward directions, respectively, and

$$
U_{10}= \begin{cases}\left|A \frac{\tanh \psi+1}{2} \sin \phi\right|, & \text { if }-\pi \leq \phi \leq \pi \\ 0.01, & \text { otherwise }\end{cases}
$$

where $A$ was $10 \mathrm{~m} \mathrm{~s}^{-1}$, and all other variables were the same as for the pressure forcing.

The model locations corresponding to tide gauges at Boulogne and Dieppe showed that wind changed the resultant maximum sea surface height by a few centimeters (Figs. 10a,b). The first peak of the wave increased at Boulogne from 0.24 to $0.27 \mathrm{~m}(+13 \%)$. At Dieppe a similar increase is seen in the first peak, increasing from 0.14 to $0.17 \mathrm{~m}(+21 \%)$. This was a $16 \%$ average increase in first peaks. The second wave peak was reduced by the wind by similar magnitudes; at Dieppe, the secondary peak decreased from 0.15 to $0.14 \mathrm{~m}(-6.7 \%)$. Overall, the wind forcing was secondary to the pressure forcing for this meteotsunami.

The contribution from wind here was small compared to meteotsunamis generated by similar convective systems in the Great Lakes. Wind stress contribution can be large because of shallow water depths (Anderson et al. 2015), strong winds (Bechle and Wu 2014), or a combination of both factors (Šepić and Rabinovich 2014). Even with similar atmospheric forcings, wind stress and pressure disturbances may contribute different amounts to wave height between different basins owing to basin bathymetry and geometry (Šepić and Rabinovich 2014). In Lake Erie, wind stress has accounted for up to $59 \%$ of wave heights because of shallow average water depths $(20 \mathrm{~m})$, despite moderate observed wind speeds (10-15 $\mathrm{m} \mathrm{s}^{-1}$ ) (Anderson et al. 2015). In Lake Michigan, wind stress has contributed up to $40 \%$ of the wave height because of high $10-\mathrm{m}$ wind speeds $\left(25 \mathrm{~m} \mathrm{~s}^{-1}\right)$, despite deeper water (75-90 m) (Bechle and Wu 2014). Further analysis for the 23 June 2016 meteotsunami has suggested that if the $10-\mathrm{m}$ wind speeds were larger $\left(25 \mathrm{~m} \mathrm{~s}^{-1}\right)$ or the Proudman-resonant water depths were shallower $(20 \mathrm{~m})$, wind stress would have contributed $30 \%-50 \%$ of the wave height. The contribution of wind here was low $(16 \%)$ because of low $10-\mathrm{m}$ wind speeds and deep water.

\section{f. Tides}

Previous calculations (section 2c) have shown that tides may have changed the location of Proudman resonance through local depth change and currents, which may have affected propagation speed and wave growth. Therefore, tides were included using boundary conditions from the TPXO European shelf model. Tide was spun up from a cold start from 0000 UTC 17 June 2016. A larger mesh with maximum 5-km node spacing extended the previous mesh across the western English Channel and above the southern North Sea amphidrome. Maximum modeled currents were $\sim 3 \mathrm{~m} \mathrm{~s}^{-1}$ near Cherbourg, and tidal ranges were about $10 \%$ smaller than observations, which were reasonable compared to other English Channel tidal models (Pingree and Maddock 1977; Davies 1986). It was not our intention to develop a precise tidal model, rather to adequately simulate tides to assess their influence.

Three simulations including tides were run, with highpass-filtered sea level results shown in Fig. 11. With the best-estimate model forcing $\left(U=19 \mathrm{~m} \mathrm{~s}^{-1} ; p_{t}=1 \mathrm{hPa}\right)$, the tidal model produced a $0.43-\mathrm{m}$ maximum wave height at Boulogne, which was $0.07 \mathrm{~m}$ smaller than the nontidal model (14\% decrease); at Dieppe the tidal model wave height was $0.15 \mathrm{~m}$, which was $0.18 \mathrm{~m}$ smaller than the nontidal model ( $56 \%$ decrease). Reducing the atmospheric forcing speed to $18 \mathrm{~m} \mathrm{~s}^{-1}$ and increasing the pressure perturbation to $1.5 \mathrm{hPa}$ produced a meteotsunami that was closer to observations and bestestimate results. The $18 \mathrm{~m} \mathrm{~s}^{-1}, 1.5$-hPa, tidal model produced a $0.30-\mathrm{m}$ maximum wave height at Dieppe and 

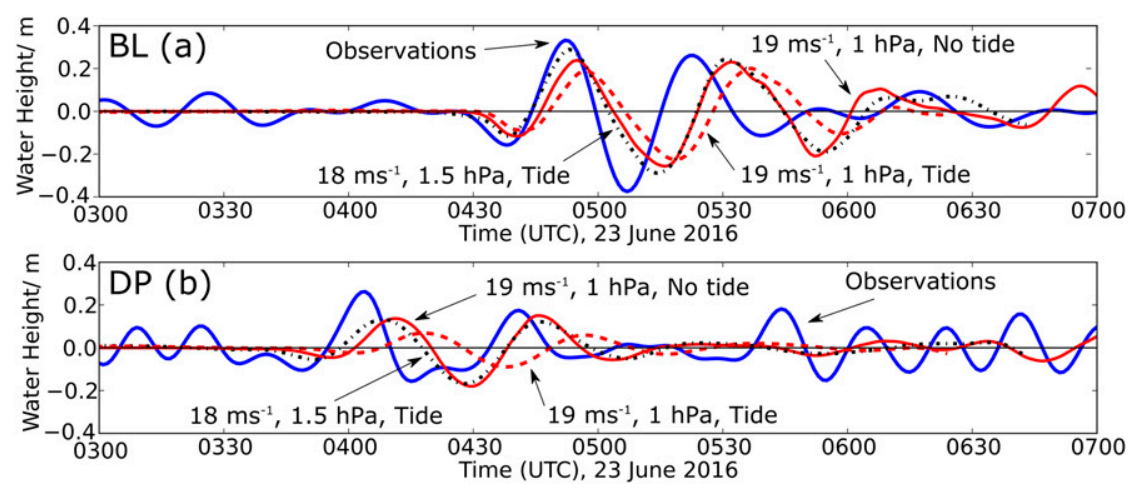

FIG. 11. Sensitivity of the meteotsunami to tides in the model. (a) Boulogne, (b) Dieppe. Blue: 10-60-min bandpass-filtered observations. Red solid line: forcing model $U=19 \mathrm{~m} \mathrm{~s}^{-1}$, $\theta=45^{\circ}, T=36 \mathrm{~min}$, and $p_{t}=1 \mathrm{hPa}$ without tides. Red dashed line: atmospheric forcing as in the red solid line but with tides. Black dash-dotted line: for the model $U=18 \mathrm{~m} \mathrm{~s}^{-1}, \theta=45^{\circ}$, $T=36 \mathrm{~min}$, and $p_{t}=1.5 \mathrm{hPa}$ with tides.

0.58-m maximum wave height at Boulogne. A model with $U=18 \mathrm{~m} \mathrm{~s}^{-1}$ and $p_{t}=1 \mathrm{hPa}$ was also run (not shown), with maximum wave heights of $0.2 \mathrm{~m}$ at Dieppe and $0.39 \mathrm{~m}$ at Boulogne. All tidal simulations produced small wave heights at Le Havre and Newhaven.

With tides included, the wave height changed at Dieppe because the Proudman resonant region shifted away from the coastline. In the numerical model, this occurred because southwestward tidal currents slowed the northeastward-propagating meteotsunami by up to $1 \mathrm{~m} \mathrm{~s}^{-1}$ (about $5 \%-6 \%$ decrease), and the tidal elevation lowered water levels by up to $0.5 \mathrm{~m}$, reducing the meteotsunami wave speed by $0.1 \mathrm{~m} \mathrm{~s}^{-1}$ (about $0.5 \%-0.6 \%$ decrease). Therefore, currents were mainly responsible for slowing the wave. Combined tidal effects reduced the shallow-water wave speed by $1.1 \mathrm{~m} \mathrm{~s}^{-1}$, meaning that the Proudman resonant region shifted toward deeper water, farther from the coast. This partially explains how larger wave heights at Dieppe were reproduced when the forcing speed was decreased by $1 \mathrm{~m} \mathrm{~s}^{-1}$ - the Proudman resonant region moved nearer the coastline.

However, when forcing speed was decreased, increasing pressure amplitude by 1.5 times was required to simulate similar wave heights to the best-estimate model. This may be because of refraction of the wave due to currents offshore, leading to larger wave heights toward the center of the basin. The processes acting to decrease the coastal wave height were more important than steepening of the wave as it was moved against the current, leading to an overall decrease in wave height.

These simulations show that tides can change the location where Proudman resonance occurs, leading to a decrease of coastal wave height on the same order of magnitude as changing the atmospheric forcing parameters. Previous studies suggest that, even in macrotidal regimes, tides only change wave heights in open basins (i.e., no seiching) by 17\% (Choi et al. 2014). This study shows that, even when tides are near still water level, tidal currents can considerably change the location of wave amplification and halve coastal wave heights.

Here, the best-estimate model underpredicted wave height even without tidal influence. Meteotsunamis are often difficult to simulate in both synthetic and NWP models (Anderson et al. 2015), particularly after the first peak (Choi et al. 2014) and across multiple locations (Hibiya and Kajiura 1982; Bechle and Wu 2014). Here, the tide reduced the meteotsunami wave height, decreasing the best-estimate wave height accuracy from $77 \%$ to $35 \%$ at Dieppe and from $71 \%$ to $61 \%$ at Boulogne. When the atmospheric forcing was altered within observational uncertainties, the wave height accuracy increased to $70 \%$ at Dieppe and to $83 \%$ at Boulogne, but the observed wave height was not fully resolved. These tidal results highlight the importance of accurately interpreting sparse observations, implementing accurate model forcings, and accounting for observational uncertainty when modeling meteotsunamis.

\section{Conclusions}

We have combined observations and numerical models to show that meteotsunamis are generated in the English Channel by convective weather systems. We demonstrate for the first time in an English Channel case study that atmospheric pressure forcing, Proudman resonance, and shoaling were key amplification mechanisms. Wind stress was a secondary forcing and increased the first wave peak by $16 \%$ on average because of combined low wind speeds and deep water. Including tide in our model decreased the coastal wave height by more than $50 \%$, mostly because tidal currents shifted the Proudman resonant region away from the coastline 
(rather than depth changes affecting the shallow-water wave propagation speed directly).

The synthetic forcing simplicity may explain differences between best-estimate model results and observations. The best-estimate simulated arrival times and wave period within minutes and captured Proudman resonance, leading to estimates of wave heights accurate to within tens of centimeters $(23 \%-29 \%$ underestimates). Here, ensembles accounted for this uncertainty, testing the sensitivity of the meteotsunami height to pressure perturbation amplitude, forcing velocity and forcing period. Nevertheless, considerable changes were found in wave height when testing sensitivity to each parameter. Wave height was linearly proportional to pressure amplitude, which is a well-known result. Forcing velocity and forcing period produced more complex changes in final wave height. Varying forcing speed between 17 and $19 \mathrm{~m} \mathrm{~s}^{-1}$ and forcing direction between $35^{\circ}$ and $55^{\circ}$ changed wave heights between 0.19 and $0.59 \mathrm{~m}$ at Dieppe and between 0.20 and $0.52 \mathrm{~m}$ at Boulogne, by changing where wave amplification occurred through Proudman resonance. Changes in forcing period resulted in complex wave behavior after the primary peak, due to superposition of different components of the meteotsunami. We recommend that future studies use an ensemble approach including tides, and varying forcing period and forcing velocity.

This study has also shown, through models covering observational uncertainty, that cross correlation of radarderived precipitation is accurate enough to estimate atmospheric forcing velocity. Advantages of the crosscorrelation method are that interpretations of gust fronts are not needed, estimates of velocity error are obtained, and the forcing velocity is calculated over water. It is also possible to calculate in near-real time in the United Kingdom—given radar measurements every $5 \mathrm{~min}$. To obtain accurate results from precipitation cross correlation in convective systems, the effects of individual cell motion should be minimized by using longer time steps and rain-rate thresholds. Once these sources of error are addressed, cross correlation of radar data is an accurate, simple method to calculate atmospheric system velocity.

Although atmospheric observations have both high temporal and spatial resolution, oceanographic observations could be improved with higher-frequency observations at tide gauges. Tide gauges in the United Kingdom and elsewhere use long averaging periods to improve the accuracy of data for long-term sea level studies. However, this hinders an improved understanding of potentially hazardous meteotsunamis where a shorter averaging period is recommended. It is also unclear how sea level rise will affect future meteotsunami hazard. A small increase in the average sea level could decrease the return period of 1 in 100 year storm surges by 25-40-fold (Wahl 2017). If meteotsunamis also become more frequent (for example from increased convective activity in a warmer atmosphere), the ability to observe them will be fundamental to coastal protection. High-frequency radar tide gauges could be a solution; they are capable of measuring water level at 1-min intervals and are relatively cheap and easy to maintain (Woodworth and Smith 2003).

We have demonstrated that convective systemgenerated meteotsunamis can be simulated using simple synthetic models. This could lead to potentially useful hazard warning systems for northwestern European seas, as has been conducted in the Adriatic (Šepić et al. 2015). We have also shown that meteotsunamis around the United Kingdom can be explained using dynamical arguments, and we have accurately simulated an observed meteotsunami by using sufficiently sampled pressure, wind, and radar data.

Acknowledgments. David Williams is funded by the National Environmental Research Council's Understanding the Earth, Atmosphere and Ocean Doctoral Training Programme, Grant NE/L002469/1. We thank Lotfi Aouf from MétéoFrance for providing 1-min atmospheric wind speed and pressure data, and two anonymous reviewers for their comments.

\section{REFERENCES}

Anderson, E. J., A. J. Bechle, C. H. Wu, D. J. Schwab, G. E. Mann, and K. A. Lombardy, 2015: Reconstruction of a meteotsunami in Lake Erie on 27 May 2012: Roles of atmospheric conditions on hydrodynamic response in enclosed basins. J. Geophys. Res. Oceans, 120, 8020-8038, https://doi.org/10.1002/2015JC010883.

Bechle, A. J., and C. H. Wu, 2014: The Lake Michigan meteotsunamis of 1954 revisited. Nat. Hazards, 74, 155-177, https://doi.org/ 10.1007/s11069-014-1193-5.

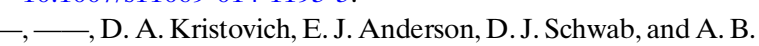
Rabinovich, 2016: Meteotsunamis in the Laurentian Great Lakes. Sci. Rep., 6, 37832, https://doi.org/10.1038/srep37832.

Belušić, D., and N. S. Mahović, 2009: Detecting and following atmospheric disturbances with a potential to generate meteotsunamis in the Adriatic. Phys. Chem. Earth, 34, 918-927, https://doi.org/10.1016/j.pce.2009.08.009.

Canadian Hydraulics Centre, 2016: Blue Kenue. National Research Council Canada, accessed 29 April 2016, https://www.nrc-cnrc. gc.ca/eng/solutions/advisory/blue_kenue_index.html.

Choi, B. J., C. Hwang, and S. H. Lee, 2014: Meteotsunami tide interactions and high frequency sea level oscillations in the eastern Yellow Sea. J. Geophys. Res. Oceans, 119, 6725-6742, https://doi.org/10.1002/2013JC009788.

Churchill, D. D., S. H. Houston, and N. A. Bond, 1995: The Daytona Beach wave of 3-4 July 1992: A shallow-water gravity wave forced by a propagating squall line. Bull. Amer. Meteor. Soc., 76, 21-32, https://doi.org/10.1175/1520-0477(1995)076<0021: TDBWOJ $>2.0 . \mathrm{CO} ; 2$. 
Davies, A., 1986: A three-dimensional model of the northwest European continental shelf, with application to the M4 tide. J. Phys. Oceanogr., 16, 797-813, https://doi.org/10.1175/1520-0485(1986) 016<0797:ATDMOT $>2.0 . \mathrm{CO} ; 2$.

Ewing, M., F. Press, and W. L. Donn, 1954: An explanation of the Lake Michigan Wave of 26 June 1954. Science, 120, 684-686, https://doi.org/10.1126/science.120.3122.684.

Frère, A., C. Daubord, A. Gailler, and H. Hébert, 2014: Sea level surges of June 2011 in the NE Atlantic Ocean: Observations and possible interpretation. Nat. Hazards, 174, 179-196, https://doi.org/10.1007/s11069-014-1103-x.

Greenspan, H. P., 1956: The generation of edge waves by moving pressure distributions. J. Fluid Mech., 1, 574-592, https:// doi.org/10.1017/S002211205600038X.

Haslett, S. K., H. E. Mellor, and E. A. Bryant, 2009: Meteo-tsunami hazard associated with summer thunderstorms in the United Kingdom. Phys. Chem. Earth, 34, 1016-1022, https://doi.org/ 10.1016/j.pce.2009.10.005.

Hervouet, J.-M., 2000: TELEMAC modelling system: An overview. Hydrol. Processes, 14, 2209-2210, https://doi.org/10.1002/ 1099-1085(200009)14:13<2209::AID-HYP23>3.0.CO;2-6.

Hibiya, T., and K. Kajiura, 1982: Origin of the Abiki phenomenon (a kind of seiche) in Nagasaki Bay. J. Meteor. Soc. Japan, 38, 172-182.

IOC, IHO, and BODC, 2003: GEBCO Digital Atlas. Centenary ed. British Oceanographic Data Centre, CD-ROM.

Kalnay, E., and Coauthors, 1996: The NCEP/NCAR 40-Year Reanalysis Project. Bull. Amer. Meteor. Soc., 77, 437-471, https:// doi.org/10.1175/1520-0477(1996)077<0437:TNYRP > 2.0.CO;2.

Large, W., and S. Pond, 1981: Open ocean momentum flux measurements in moderate to strong winds. J. Phys. Oceanogr., 11, 324-336, https://doi.org/10.1175/1520-0485(1981)011<0324: OOMFMI $>2.0 . \mathrm{CO} ; 2$.

Levin, B. W., and M. Nosov, 2009: Physics of Tsunamis. Springer, 388 pp.

Ličer, M., B. Mourre, C. Troupin, A. Krietemeyer, A. Jansaá, and J. Tintoré, 2017: Numerical study of the Balearic meteotsunami generation and propagation under synthetic gravity wave forcing. Ocean Modell., 111, 38-45, https://doi.org/ 10.1016/j.ocemod.2017.02.001.

Linares, A., and A. J. Bechle, 2018: Meteotsunami-induced rip currents on 4 July 2003 in Warren Dunes, Lake Michigan. 2018 Ocean Sciences Meeting, Portland, OR, Amer. Geophys. Union, PO31A-03.

Markowski, P., and Y. Richardson, 2011: Mesoscale Meteorology in Midlatitudes. Vol. 2. John Wiley \& Sons, $430 \mathrm{pp}$

Met Office, 2003: Met Office rain radar data from the NIMROD system. NCAS British Atmospheric Data Centre, accessed 9 February 2017, http://catalogue.ceda.ac.uk/ uuid/82adec1f896af6169112d09cc1174499.

Monserrat, S., I. Vilibić, and A. Rabinovich, 2006: Meteotsunamis: Atmospherically induced destructive ocean waves in the tsunami frequency band. Nat. Hazards Earth Syst. Sci., 6, 10351051, https://doi.org/10.5194/nhess-6-1035-2006.

Pingree, R., and L. Maddock, 1977: Tidal residuals in the English Channel. J. Mar. Biol. Assoc. U. K., 57, 339-354, https://doi.org/ 10.1017/S0025315400021792.

Proudman, J., 1929: The effects on the sea of changes in atmospheric pressure. Geophys. J. Int., 2, 197-209, https://doi.org/ 10.1111/j.1365-246X.1929.tb05408.x.
Pugh, D., and P. Woodworth, 2014: Sea-Level Science: Understanding Tides, Surges, Tsunamis And Mean Sea-Level Changes. Cambridge University Press, 203 pp.

Rabinovich, A. B., and S. Monserrat, 1998: Generation of meteorological tsunamis (large amplitude seiches) near the Balearic and Kuril Islands. Nat. Hazards, 18, 27-55, https://doi.org/ 10.1023/A:1008096627047.

Šepić, J., and A. B. Rabinovich, 2014: Meteotsunami in the Great Lakes and on the Atlantic coast of the United States generated by the "derecho" of June 29-30, 2012. Nat. Hazards, 74, 75107, https://doi.org/10.1007/s11069-014-1310-5.

_ - I. Vilibić, and N. S. Mahović, 2012: Northern Adriatic meteorological tsunamis: Observations, link to the atmosphere, and predictability. J. Geophys. Res., 117, C02002, https://doi.org/ 10.1029/2011JC007608.

_, - and I. Fine, 2015: Northern Adriatic meteorological tsunamis: Assessment of their potential through ocean modeling experiments. J. Geophys. Res. Oceans, 120, 2993-3010, https://doi.org/10.1002/2015JC010795.

Sheremet, A., U. Gravois, and V. Shrira, 2016: Observations of meteotsunami on the Louisana shelf: A lone soliton with a soliton pack. Nat. Hazards, 84, 471-492, https://doi.org/10.1007/ s11069-016-2446-2.

Sibley, A., D. Cox, D. Long, D. Tappin, and K. Horseburgh, 2016: Meteorologically generated tsunami-like waves in the North Sea on 1/2 July 2015 and 28 May 2008. Weather, 71, 68-74, https://doi.org/10.1002/wea.2696.

Tappin, D. R., A. Sibley, K. Horsburgh, C. Daubord, D. Cox, and D. Long, 2013: The English Channel "tsunami" of 27 June 2011: A probable meteorological source. Weather, 68, 144 152, https://doi.org/10.1002/wea.2061.

Vennell, R., 2010: Resonance and trapping of topographic transient ocean waves generated by a moving atmospheric disturbance. J. Fluid Mech., 650, 427-442, https://doi.org/10.1017/ S0022112009993739.

Vilibić, I., 2008: Numerical simulations of the Proudman resonance. Cont. Shelf Res., 28, 574-581, https://doi.org/10.1016/ j.csr.2007.11.005.

__ and J. Šepić, 2017: Global mapping of nonseismic sea level oscillations at tsunami timescales. Sci. Rep., 7, 40818, https:// doi.org/10.1038/srep40818.

__ - — - A. B. Rabinovich, and S. Monserrat, 2016: Modern approaches in meteotsunami research and early warning. Front. Mar. Sci., 3, 57, https://doi.org/10.3389/fmars.2016. 00057.

Vučetić, T., I. Vilibić, S. Tinti, and A. Maramai, 2009: The Great Adriatic flood of 21 June 1978 revisited: An overview of the reports. Phys. Chem. Earth, 34, 894-903, https://doi.org/ 10.1016/j.pce.2009.08.005.

Wahl, T., 2017: Sea-level rise and storm surges, relationship status: Complicated! Environ. Res. Lett., 12, 111001, https://doi.org/ 10.1088/1748-9326/aa8eba.

Wertman, C. A., R. M. Yablonsky, Y. Shen, J. Merrill, C. R. Kincaid, and R. A. Pockalny, 2014: Mesoscale convective system surface pressure anomalies responsible for meteotsunamis along the U.S. East Coast on June 13th, 2013. Sci. Rep., 4, 7143, https://doi.org/10.1038/srep07143.

Woodworth, P. L., and D. E. Smith, 2003: A one year comparison of radar and bubbler tide gauges at Liverpool. Int. Hydrogr. Rev., 4, 42-49. 